\title{
Comparative Study on Grouting Protection Schemes for Shield Tunneling to Adjacent Viaduct Piles
}

\author{
Kan Huang $\mathbb{D}^{1,2}$ Yiwei Sun $\mathbb{D}^{1},{ }^{1}$ Jun He $\mathbb{D}^{1},{ }^{1}$ Xianqiang Huang $\mathbb{D}^{1}{ }^{1}$ \\ Meng Jiang, ${ }^{1}$ and Yujian Li (iD ${ }^{1}$ \\ ${ }^{1}$ School of Civil Engineering, Changsha University of Science and Technology, Changsha 410114, China \\ ${ }^{2}$ School of Civil Engineering, Changsha University, Changsha 410022, China \\ Correspondence should be addressed to Yiwei Sun; yiweisun@sina.cn and Jun He; hejun@csust.edu.cn
}

Received 15 February 2021; Accepted 31 July 2021; Published 11 August 2021

Academic Editor: Ivan Giorgio

Copyright (C) 2021 Kan Huang et al. This is an open access article distributed under the Creative Commons Attribution License, which permits unrestricted use, distribution, and reproduction in any medium, provided the original work is properly cited.

Shield tunnels will inevitably pass through viaduct piles at a close distance due to the extensive construction of subways and viaducts in the city. In order to understand the influence of shield tunneling on the deformation of existing pile foundation and grouting protection measures, based on an engineering case, Changsha Metro Line 5 (from South Gaoqiao station to Guitang station), a three-dimensional finite element model was established to analyze the deformation of bridge pile using grouting protection wall with different depths and shapes when the shield tunnel is under construction. The analytical results indicate that the grouting protection wall can effectively reduce the pile displacement; especially the grouting depth is $3 \mathrm{~m}$ below the bottom of the tunnel. Moreover, the L-shaped grouting protection wall can effectively reduce the longitudinal displacement of the piles. The present findings may provide a reference for the design and construction of shield tunnels passing through viaduct piles.

\section{Introduction}

With the continuous development of urbanization, in order to solve the ground traffic congestion, the viaduct and subway become important parts of urban infrastructure. Due to traffic route design and urban space constraints, shield tunnels often need to pass through existing viaduct piles. The excavation of shield tunnel may cause the deformation of surrounding soil [1-10], thus affecting the existing pile foundation. Once the deformation of the pile exceeds the limit, it will directly affect the normal operation of the superstructure and bring a series of risks for safety [11-18]. At present, a large amount of numerical research has been conducted on the additional displacement of existing pile foundation caused by shield tunneling [19-29]. Meanwhile, model tests and in situ monitoring of the displacement of adjacent pile foundation caused by shield tunneling were also performed [30-38].

Previous research focused on the investigation of the influence of shield tunneling on adjacent pile foundations by theoretical derivation and calculation analysis [39-46]. With the increase of urban spatial density, the distance between shield tunnel and pile foundation will be close. It is necessary to find out the most appropriate method to protect the adjacent pile foundation. Several scholars proposed protection measures for the pile foundation to reduce the adverse effects caused by shield tunneling [47-55]. Bilotta and Russo [49] evaluated the effectiveness of a simple row of piles to protect adjacent buildings by means of three-dimensional finite element analyses. Compared with the results of centrifuge, it is found that the settlement reduction is significant for the piles with small spacing. Bai et al. [50] adopted three different types of mitigation methods including bored piles, grouting, and construction optimization to protect the buildings near the tunnel. Fu et al. [51] evaluated the effectiveness of underground jet-grouted partition wall in mitigating the effects of shield tunneling on existing piled structures by means of numerical analysis and field monitoring. The results indicate that the presence of partition wall can relieve the existing piles from suffering uneven settlement. Wang et al. [52] discussed the project of retrofitting Fengqi Bridge and analyzed monitoring data before and after 
the shield machine crossed the bridge. Their findings indicate that reinforcement of the raft foundation and improvement of composite ground can effectively decrease bridge settlement during tunneling. Yang et al. [54] proposed a new controllable grouting method and two corresponding grouting materials to prereinforce the underwater karst region before shield tunnel passing. The results indicate that the grouting activities not only meet the engineering requirements but also are environmentally and ecologically friendly. Li et al. [55] proposed four kinds of protective schemes to guarantee the safety of existing grouped piles of Shiyou Bridge during tunnel construction and found that the deep-hole grouting scheme has a better control effect on the lateral deformation and bending moment of the piles.

With the rapid development of urban viaducts, the proportion of long piles in all pile foundations continues to increase. Previous scholars mainly carried out research on the protection of building pile foundation. However, research on viaduct piles is still not enough. Due to the great difference between building pile foundation and viaduct pile foundation in length and layout, it is urgent to find out a protection scheme suitable for long piles, especially in the process of shield passing through viaduct piles within a short distance.

This paper is organized as follows: firstly, Changsha Metro Line 5 (from South Gaoqiao station to Guitang station) was selected as an engineering background. The details of the design and construction of the shield tunnel passing through the bridge piles of Wanjiali viaduct were illustrated, including the soil parameters in this area from the preliminary geological survey. Secondly, four grouting schemes were proposed to control the deformation of the pile foundation for the tunnel passing through the viaduct pile. The most suitable grouting depth was determined after comparing and analyzing the vertical, horizontal, and longitudinal displacement of the pile using three-dimensional finite element modelling. Finally, an "L"-shaped grouting isolation scheme is proposed, which can effectively protect the adjacent bridge piles and make the shield drive smoothly.

\section{Engineering Background}

2.1. Project Overview. Changsha Metro Line 5 is located in Changsha, Hunan Province, China, as shown in Figure 1, which has a total length of 22.5 kilometers (from north to south), with 18 stations, all of which are underground stations. According to the preliminary route planning, the parallel length between Metro Line 5 and Wanjiali viaduct is about 15 kilometers. The shield tunnel passes through the viaduct piles at a close distance many times. In the present study, the representative interval tunnel from South Gaoqiao Station to Guitang Station is selected as an engineering background. Wanjiali viaduct is located at the west side of the left tunnel. The tunnel passes through the existing bridge piles and underneath the Guitang River. Influenced by existing river and ground transportation, the distance between two C35 bored concrete bridge piles with a diameter of $1.2 \mathrm{~m}$ and the left tunnel is very close. The twin tunnels made of C50 precast concrete segments, with an inner diameter of $5.4 \mathrm{~m}$ and a buried depth of $19.2 \mathrm{~m}$, having a lining thickness of $0.3 \mathrm{~m}$ and width of $1.5 \mathrm{~m}$, were excavated using earth pressure balance shield tunnel boring machine.

The considered area is located between the design mileage ZDK27+352.322 and ZDK27+397.322, as illustrated in Figure 2. The nearest distance between the left tunnel and the pile of Wanjiali viaduct is only $3.07 \mathrm{~m}$.

2.2. Site Condition. According to a previous geological drilling report, there are 5 layers of soil from the ground surface to the depth of $70 \mathrm{~m}$, which are miscellaneous fill, silty clay, bubble, strongly weathered conglomerate, and moderately weathered conglomerate. The underground stable water level is located at a depth of $7.8 \mathrm{~m}$. In addition, the bedrock of the site can be divided into two zones of high weathering and moderate weathering within the scope of investigation depth. The highly weathered conglomerate is grayish white with purplish red, partly with thin layers of argillaceous siltstone, clastic structure, and massive structure. The natural compressive strength is from 1.19 to $1.96 \mathrm{MPa}$, and the average value is $1.59 \mathrm{MPa}$. The moderately weathered conglomerate is purplish red with clastic structure, thick laminated structure, mainly argillaceous cementation. The natural compressive strength ranges from 6.15 to $18.67 \mathrm{MPa}$, with an average of $10.57 \mathrm{MPa}$.

As shown in Figure 3, the pile bearing layer of the Wanjiali viaduct is a moderately weathered conglomerate and the shield tunnels are located in the strongly weathered conglomerate. Physical and mechanical parameters of surrounded layers are listed in Table 1.

\section{Grouting Isolation Protection Schemes}

Shield tunneling will cause uneven settlement of surrounding soil, leading to the deformation of adjacent bridge piles. Especially when the pile foundation is close to the shield tunnel, the excessive deformation will affect the normal operation of the superstructure. At present, highpressure rotary jet grouting isolation protection is generally applied for the existing bridge piles under such condition. However, the grouting depth has not been clearly defined. Since the displacement of bridge pile caused by shield tunneling is mainly concentrated near the location of the tunnel, it is necessary to consider whether to isolate the tunnel area by grouting. In addition, the diameter ot the urban shield tunnel is $6 \mathrm{~m}$, and the grouting depth should be increased successively based on the radius of the shield tunnel, which can better compare the grouting control effect at different depths. As shown in Figure 4, this paper proposes four grouting isolation protection schemes with different grouting depths, such as at the top of the tunnel, at the bottom of the tunnel, and at $3 \mathrm{~m}$ and $6 \mathrm{~m}$ below the bottom of the tunnel, respectively. Grouting isolation is set in the middle of the connection between pile and tunnel and a little closer to the pile.

Using the finite element method, the vertical, horizontal, and longitudinal displacement of the pile under four different grouting isolation protection schemes are obtained 


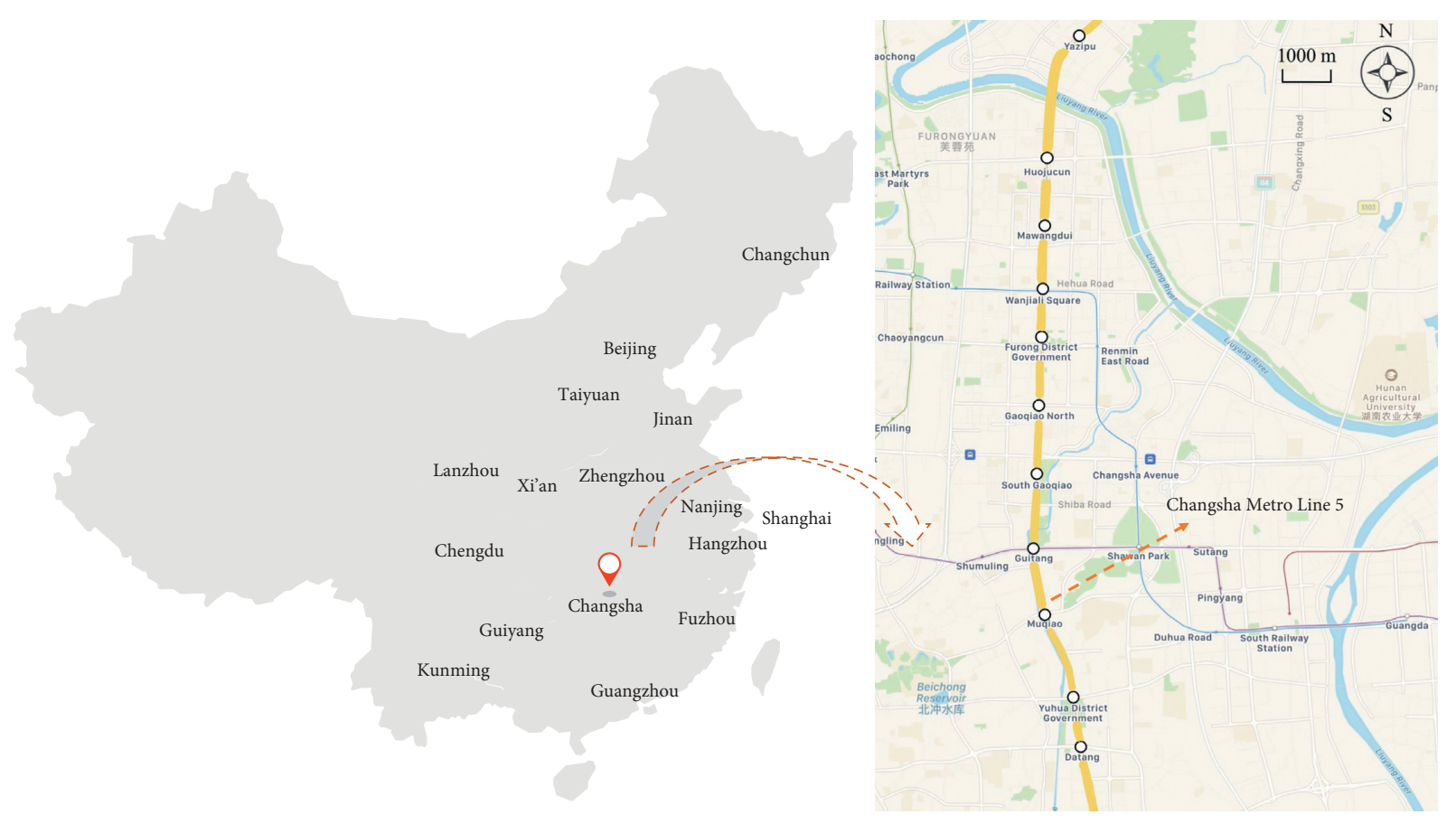

Figure 1: The location of Changsha Metro Line 5.
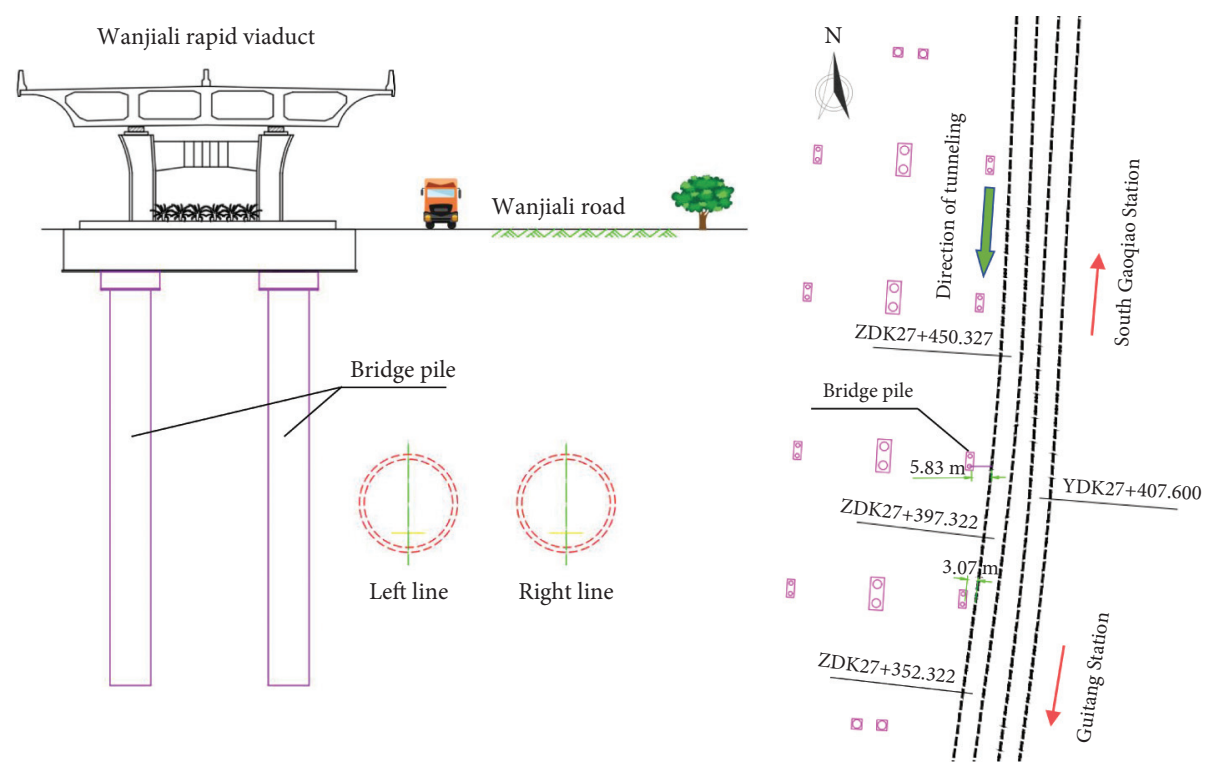

Figure 2: Location of the bridge pile and shield tunnel.

and compared to determine the suitable grouting depth for protecting the existing bridge pile.

\section{Numerical Simulation}

4.1. Numerical Model. The finite element software Midas GTS NX was employed for numerical simulation. A threedimensional finite element model was established, including twin tunnels, bridge piles, grouting isolation wall, and surrounding soil, as shown in Figure 5. In order to decrease the boundary effects of the model and ensure the accuracy of finite element calculation, the dimensions of the three-dimensional model were chosen as $60 \mathrm{~m}$ in length, $50 \mathrm{~m}$ in width, and $70 \mathrm{~m}$ in height. In order to simplify the calculation, the soil was treated as the horizontally layered foundation. The pile length was $50 \mathrm{~m}$, the nearest distance of the pile to the left tunnel was $3.07 \mathrm{~m}$, and the buried depth of the tunnel was $19.2 \mathrm{~m}$. A grouting isolation wall with $6 \mathrm{~m}$ in length and $1 \mathrm{~m}$ in width was modelled between the bridge pile and the shield tunnel.

Shield segments were simulated by two-dimensional plate elements, while the soil, pile foundation, segment backfill 


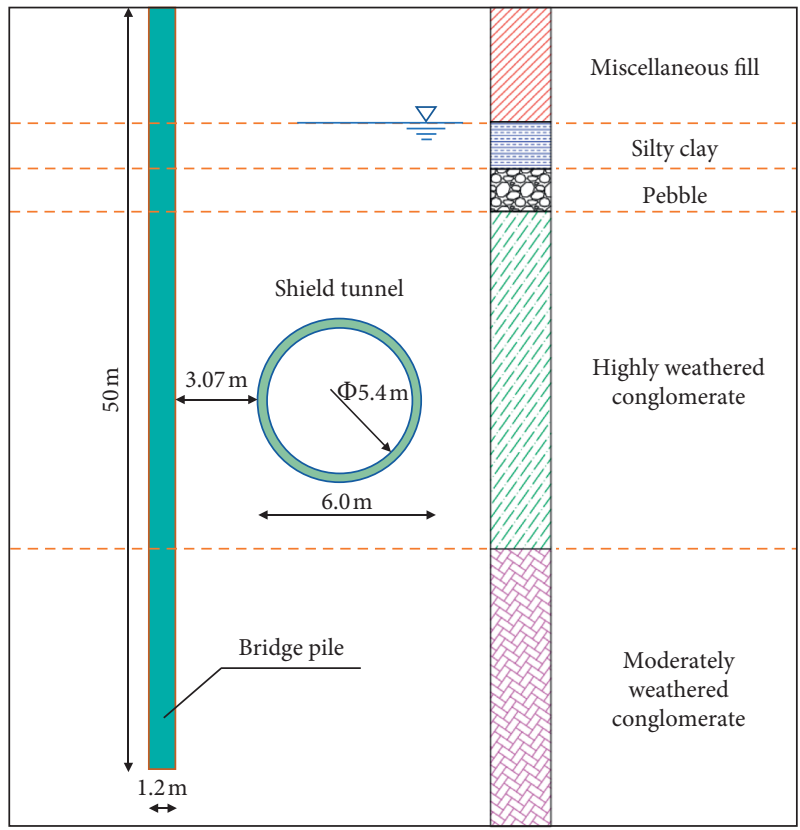

FIGURE 3: Engineering geology profile.

TABle 1: Physical mechanical parameters of surrounded layers.

\begin{tabular}{|c|c|c|c|c|c|c|c|}
\hline Soil type at each layer & $\begin{array}{c}\text { Thickness } H \\
(\mathrm{~m})\end{array}$ & $\begin{array}{c}\text { Elasticity } \\
\text { modulus } E \\
(\mathrm{MPa})\end{array}$ & $\begin{array}{l}\text { Poisson's } \\
\text { ratio } \mu\end{array}$ & $\begin{array}{l}\text { Unit weight } \gamma \\
\left(\mathrm{kN} \cdot \mathrm{m}^{-3}\right)\end{array}$ & $\begin{array}{c}\text { Cohesion } c \\
(\mathrm{kPa})\end{array}$ & $\begin{array}{c}\text { Internal } \\
\text { friction angle } \\
\varphi\left({ }^{\circ}\right)\end{array}$ & $\begin{array}{c}\text { Permeability } \\
\text { coefficient } k\left(\mathrm{~m} \cdot \mathrm{d}^{-1}\right)\end{array}$ \\
\hline (1) Miscellaneous fill & 7.8 & 8.5 & 0.35 & 19.0 & 10 & 12 & 0.700 \\
\hline (2) Silty clay & 3.2 & 15.5 & 0.30 & 20.0 & 30 & 16 & 0.008 \\
\hline (3) Pebble & 2.9 & 35.0 & 0.25 & 20.0 & 2 & 36 & 25.000 \\
\hline $\begin{array}{l}\text { (4) Highly weathered } \\
\text { conglomerate } \\
\text { (5) Moderately }\end{array}$ & 23.0 & 38.5 & 0.27 & 23.5 & 40 & 30 & 0.500 \\
\hline $\begin{array}{l}\text { weathered } \\
\text { conglomerate }\end{array}$ & 33.1 & 47.0 & 0.24 & 25.0 & 120 & 35 & 0.100 \\
\hline
\end{tabular}

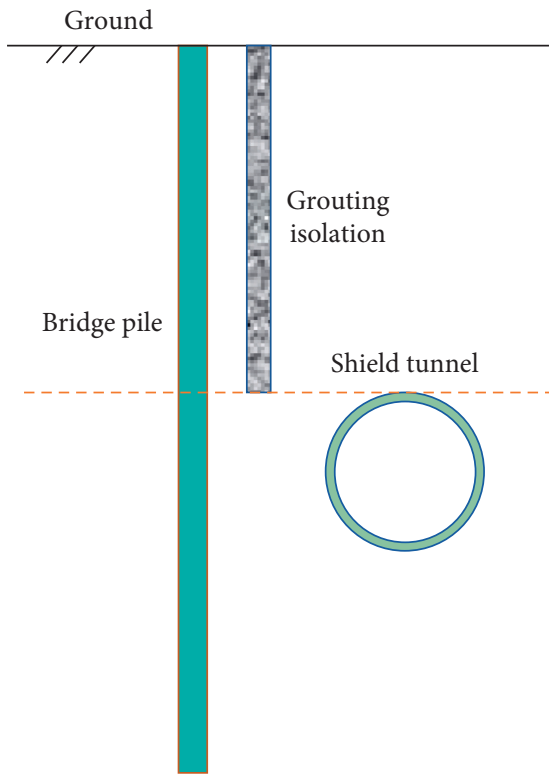

(a)

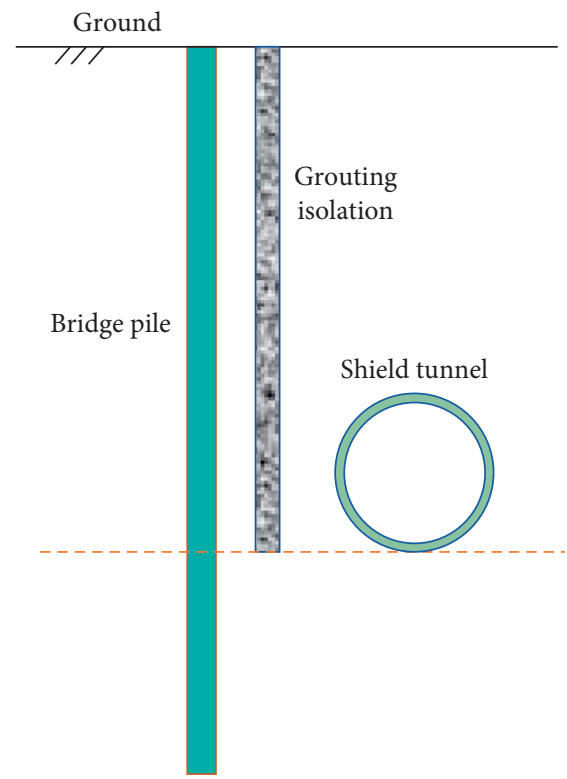

(b)

Figure 4: Continued. 


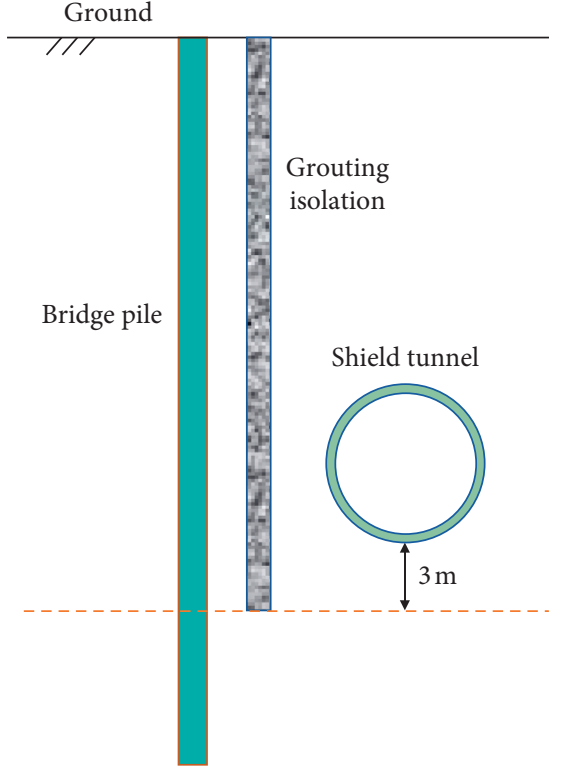

(c)

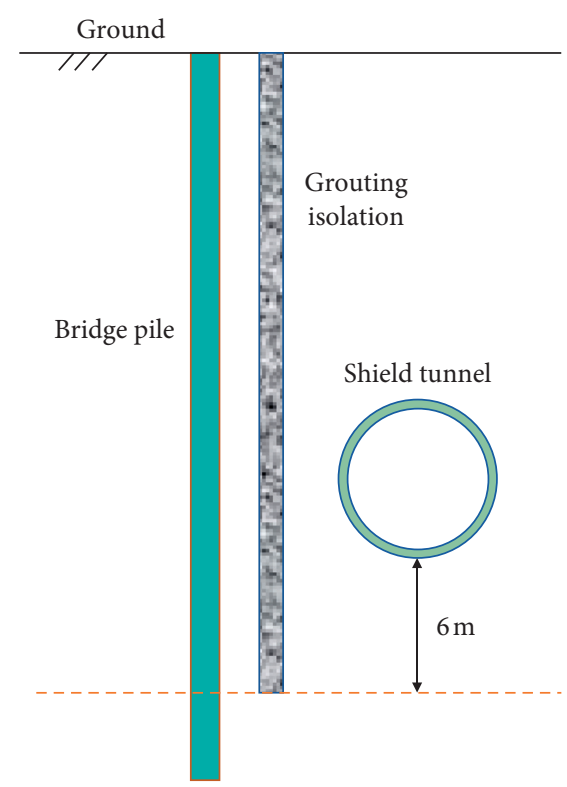

(d)

FIGURE 4: Grouting reinforcement scheme: (a) grouting to the top of the tunnel; (b) grouting to the bottom of the tunnel; (c) grouting to $3 \mathrm{~m}$ below the bottom of the tunnel; (d) grouting to $6 \mathrm{~m}$ below the bottom of the tunnel.

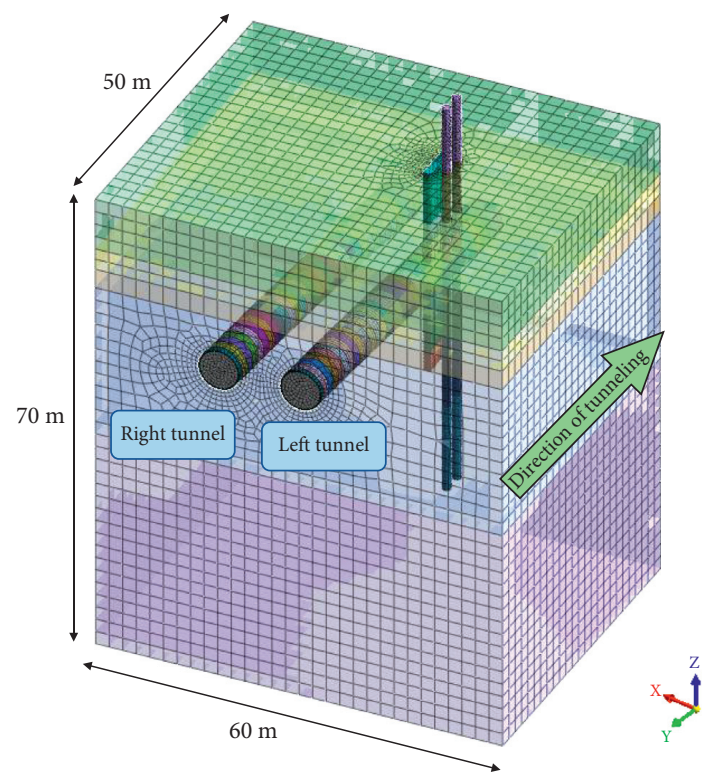

Figure 5: Three-dimensional finite element model.

grouting, and grouting isolation wall were simulated by threedimensional solid elements. The interaction between pile and soil was established according to node coupling, which can eliminate the inaccuracy caused by improper parameter setting of pile-soil interface element when $1 \mathrm{D}$ beam elements were used. The interaction between different soil layers was also established through node coupling. The mesh size of the concerned areas, such as shield tunnel, pile foundation, and grouting isolation wall was mesh refined. The model had a total of 284301 elements and 175514 nodes.
4.2. Constitutive Model and Calculation Parameters. In order to consider the effect of soil unloading caused by shield tunneling, the modified Mohr-Coulomb constitutive model of soil was selected. Shield segments and pile foundations were simplified with elastic materials. The segments were treated as homogeneous rings, made of C50 concrete, and the pile foundations were made of C35 concrete. It is assumed that a perfect bond between the pile and soil is maintained and no detachment occurs. The material parameters of bridge pile, segment, and grouting are shown in Table 2. 
TABle 2: Parameters of pile, segment, and grouting material.

\begin{tabular}{lccc}
\hline Materials & Elasticity modulus $(\mathrm{MPa})$ & Poisson's ratio & ${\text { Density }\left(\mathrm{kN} \cdot \mathrm{m}^{-3}\right)}$ \\
\hline Pile foundation & $3.15 \times 10^{4}$ & 0.3 & 23.0 \\
Shield segment & $2.415 \times 10^{4}$ & 0.2 & 25.0 \\
Grouting & $2 \times 10^{2}$ & 0.3 & 22.0 \\
\hline
\end{tabular}

4.3. Numerical Simulation Procedure. The excavation construction stage was simulated step-by-step; each excavation stage forwards $1.5 \mathrm{~m}$. The excavation construction was realized by the method of "element birth and death." In practical engineering, when the shield passes through the important structures, the thrust force of the shield machine should be controlled between $7000 \mathrm{kN}$ and $9000 \mathrm{kN}$. Thus, the thrust force of the shield is chosen as $8000 \mathrm{kN}$ in this study. After the excavation at the current position is completed, the shield segment is installed, and then the segment backfill grouting will be performed. The grouting pressure behind the segment is generally between $0.4 \mathrm{MPa}$ and $0.8 \mathrm{MPa}$, so the grouting pressure behind the segment is applied as $0.6 \mathrm{MPa}$ in this model.

\section{Comparison of Pile Displacement}

5.1. Comparison of Vertical Displacement of the Pile. Figures 6-9 show the comparison of vertical displacement of the pile using four different grouting isolation protection schemes during the tunnel construction process. The shield tunneling passing through the adjacent bridge pile foundation may cause settlement of the pile above the tunnel and separation of the pile below the tunnel if no grouting isolation protection is constructed. During the process of shield approaching the pile foundation, the vertical displacement of the pile increases gradually and continues to increase after the shield passing through the pile foundation. However, the increasing rate decreases and the vertical displacement of the pile tends to be stable after the shield passes through the pile foundation for 8 rings because the loss of soil above the top of the tunnel is caused by shield tunneling. Meanwhile, the soil below the bottom of the tunnel rebounds due to the excavation and soil unloading. Under the influence of variation of the soil displacement field, the adjacent bridge pile may deflect above the tunnel and separate below the tunnel.

By comparing the vertical displacement of the bridge pile without grouting isolation and grouting to different depths, it can be found that different grouting depths have obvious different effects on the vertical displacement of the pile foundation. When grouting depth is arranged to the top of the tunnel, the protective effect is slight when the shield has not been excavated to the pile foundation and is far from the pile foundation. With the decrease of the distance from the bridge pile, the vertical displacement of the pile when grouting to the top of tunnel is larger than that without grouting isolation. Therefore, when the depth of grouting isolation is not reasonably arranged, it will further increase the vertical displacement of the pile. When the grouting depth is set at the bottom of the tunnel, it can control the vertical displacement of the pile to some extent. The displacement at the pile top and the displacement at the lower part of the pile are reduced by $35.65 \%$ and $7.86 \%$ compared with that without grouting. When the grouting depth is set to $3 \mathrm{~m}$ below the bottom of the tunnel, it has an obvious effect on controlling the vertical displacement of the pile. The displacement at the top and bottom of the pile can be reduced by $74.28 \%$ and $12.83 \%$, respectively, when the grouting depth is $3 \mathrm{~m}$ below the bottom of the tunnel. If we further increase grouting depth to $6 \mathrm{~m}$ below the bottom of the tunnel, vertical displacement of the pile will continue to decrease. But the top of the pile shows small separation, and the vertical displacement curve distorts to a certain extent, resulting in the increment of the axial force of the bridge pier. Therefore, in terms of controlling the vertical displacement of the pile, a grouting depth of $3 \mathrm{~m}$ below the tunnel was determined as an optimal solution.

5.2. Comparison of Horizontal Displacement of the Pile. Figures 10-13 show the comparison of horizontal displacement of the pile using four different grouting isolation protection schemes during the tunnel construction process. Due to ground loss caused by shield tunneling, at the overlap of the buried depth for the pile and tunnel, some parts of the pile deform in the horizontal direction, showing an "S"-shape. Moreover, with the continuous excavation of the shield, the deformation gradually increases. Similarly, after the shield passes through the pile for 8 rings, the horizontal displacement becomes stable. When the grouting depth is set to the top of the tunnel, during the process of shield tunneling, the horizontal displacement of the pile is basically the same as that without grouting isolation. When the grouting depth is set to the bottom of the tunnel, it has a certain effect to control the horizontal displacement of the pile. The horizontal displacement at the top of the pile decreased by $6.54 \%$, and the maximum displacement near the buried depth of the tunnel reduced by $14.32 \%$ in comparison to that without grouting. When the grouting depth is set to $3 \mathrm{~m}$ below the bottom of the tunnel, the horizontal displacement of the pile is significantly improved. The horizontal displacement at the top of the pile decreased by $13.61 \%$, and the maximum displacement near the buried depth of the tunnel declined by $22.56 \%$ in comparison to that without grouting. If the grouting depth is continued to increase to $6 \mathrm{~m}$ below the bottom of the tunnel, the effect of controlling the horizontal displacement of the pile was not much improved, 


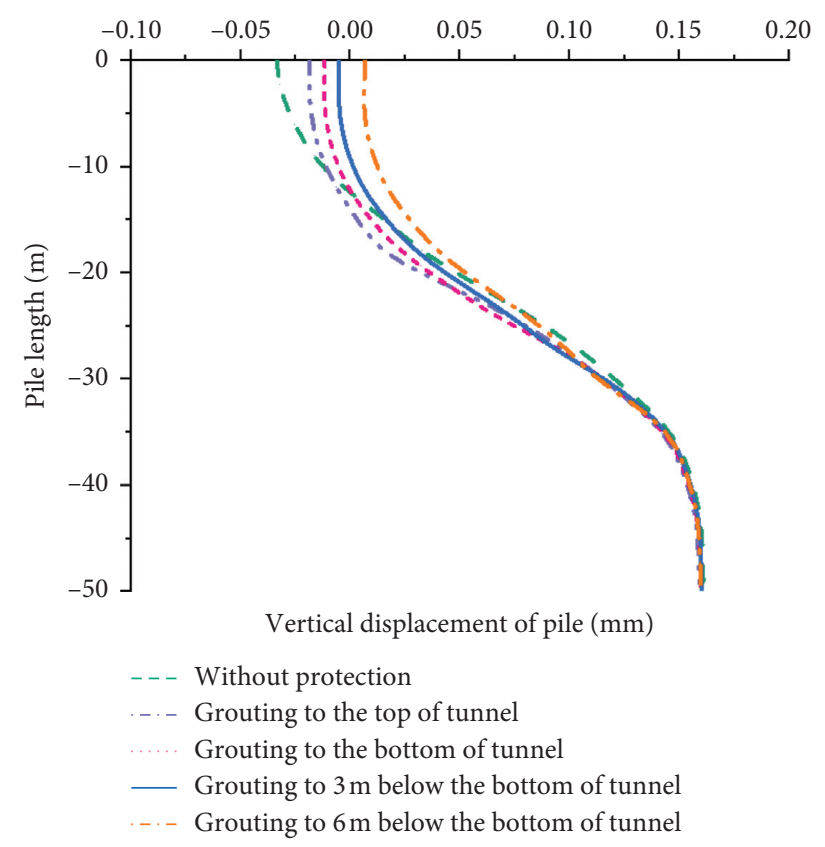

(a)

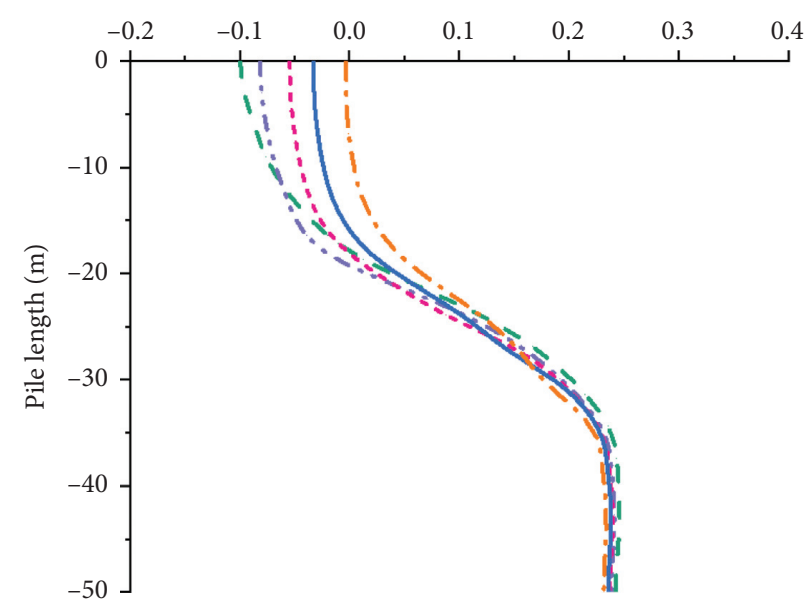

Vertical displacement of pile (mm)

Without protection

-..- Grouting to the top of tunnel

Grouting to the bottom of tunnel

- Grouting to $3 \mathrm{~m}$ below the bottom of tunnel

-.- Grouting to $6 \mathrm{~m}$ below the bottom of tunnel

(b)

FIgURE 6: Vertical displacement of the pile: (a) 6 rings before arriving at the pile; (b) 4 rings before arriving at the pile.

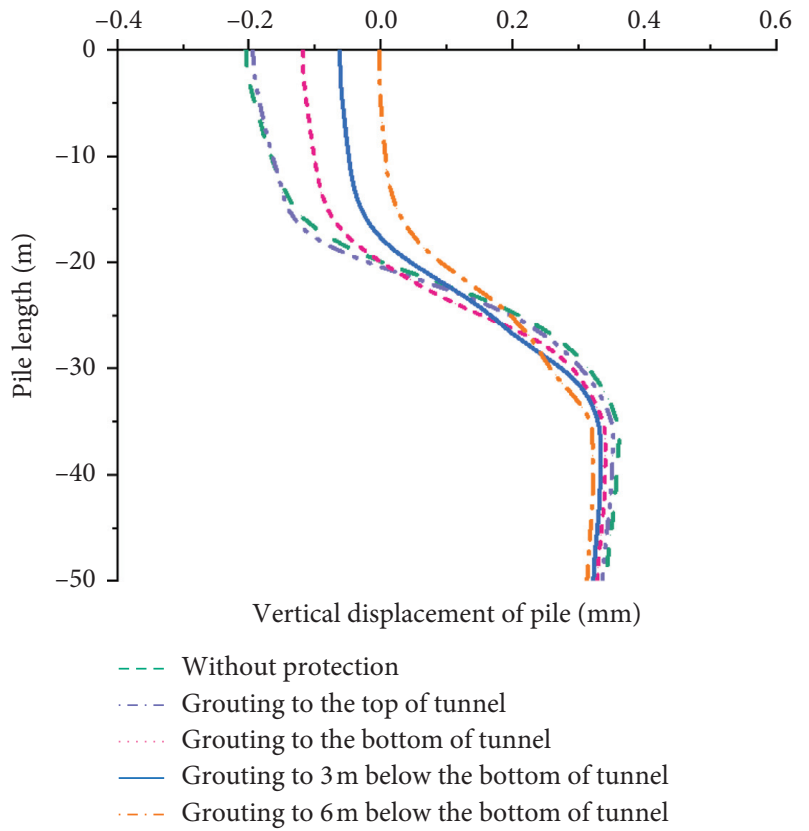

(a)

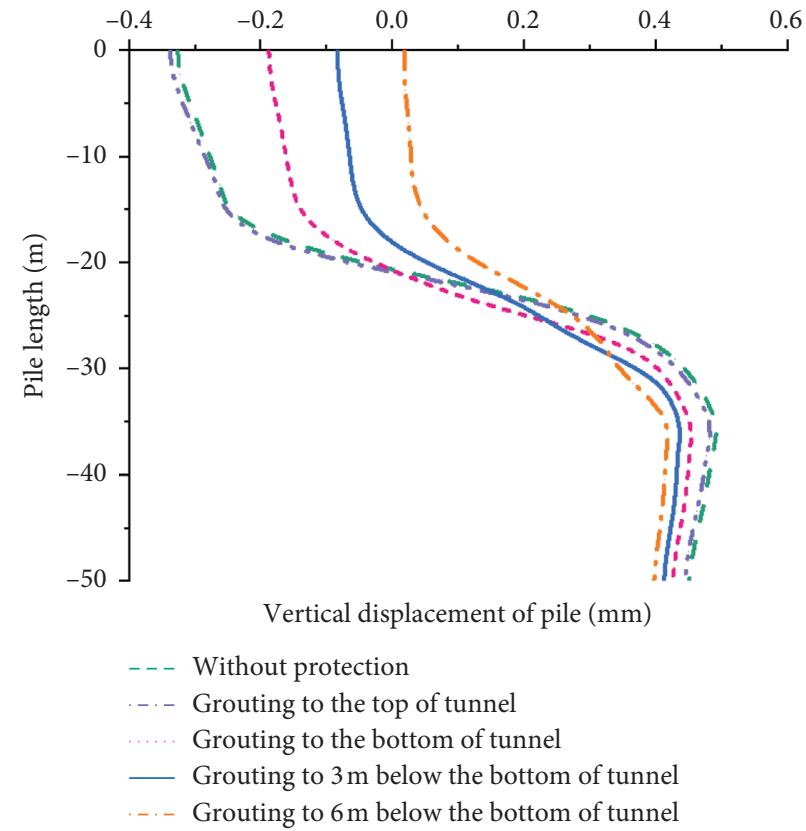

(b)

Figure 7: Vertical displacement of the pile: (a) 2 rings before arriving at the pile; (b) arriving at the pile.

compared with the effect when grouting to $3 \mathrm{~m}$ below the bottom of the tunnel, but the cost of grouting will be increased. Therefore, from the perspective of protection effect and construction cost, setting the depth of grouting isolation as $3 \mathrm{~m}$ below the tunnel is an optimal plan to control the horizontal displacement of the pile foundation.
5.3. Comparison of Longitudinal Displacement along the Tunnel of the Pile. At present, many scholars have studied the vertical and horizontal displacement of adjacent pile foundation caused by shield tunneling, but the longitudinal displacement along the tunnel of pile caused by shield tunneling was not considered. Thus, the longitudinal 

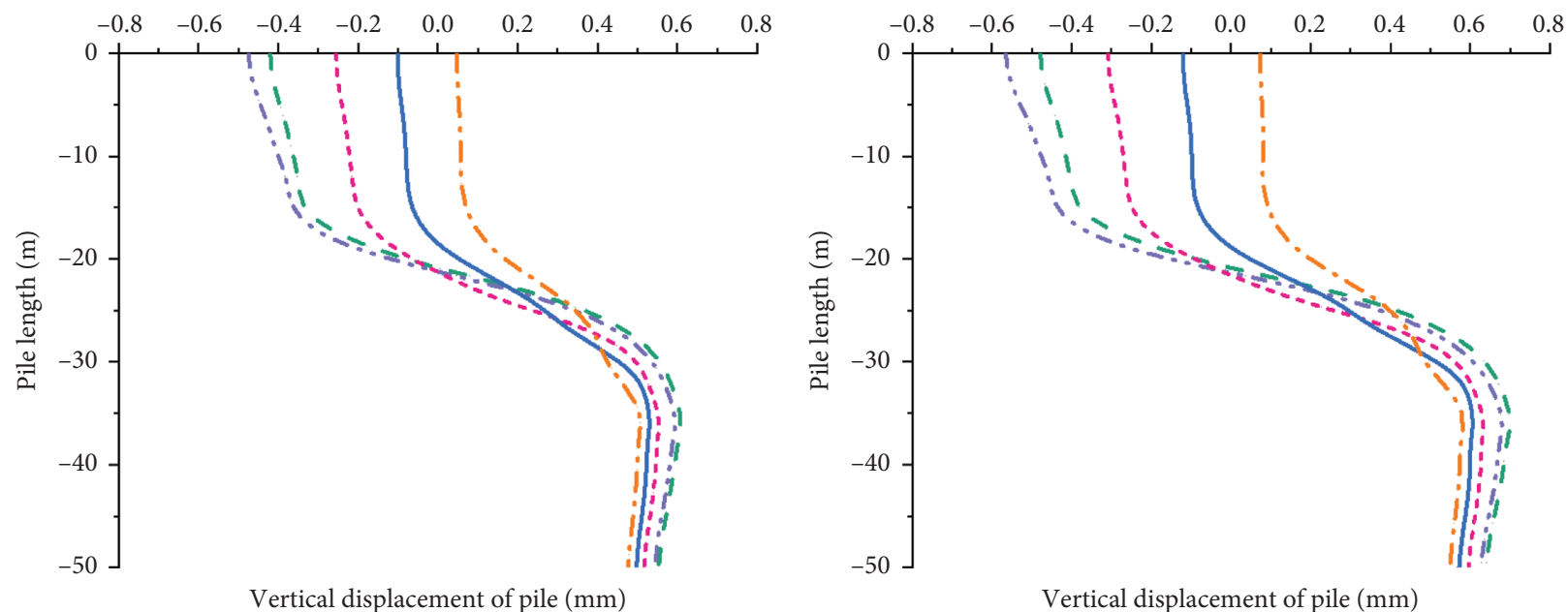

- Without protection

... Grouting to the top of tunnel Grouting to the bottom of tunnel

- Grouting to $3 \mathrm{~m}$ below the bottom of tunnel

-. - Grouting to $6 \mathrm{~m}$ below the bottom of tunnel

(a)

Vertical displacement of pile $(\mathrm{mm})$

-.- Without protection
..- Grouting to the top of tunnel
.... Grouting to the bottom of tunnel
_. Grouting to $3 \mathrm{~m}$ below the bottom of tunnel
.. Grouting to $6 \mathrm{~m}$ below the bottom of tunnel

(b)

FIGURE 8: Vertical displacement of the pile: (a) 2 rings after passing the pile; (b) 4 rings after passing the pile.

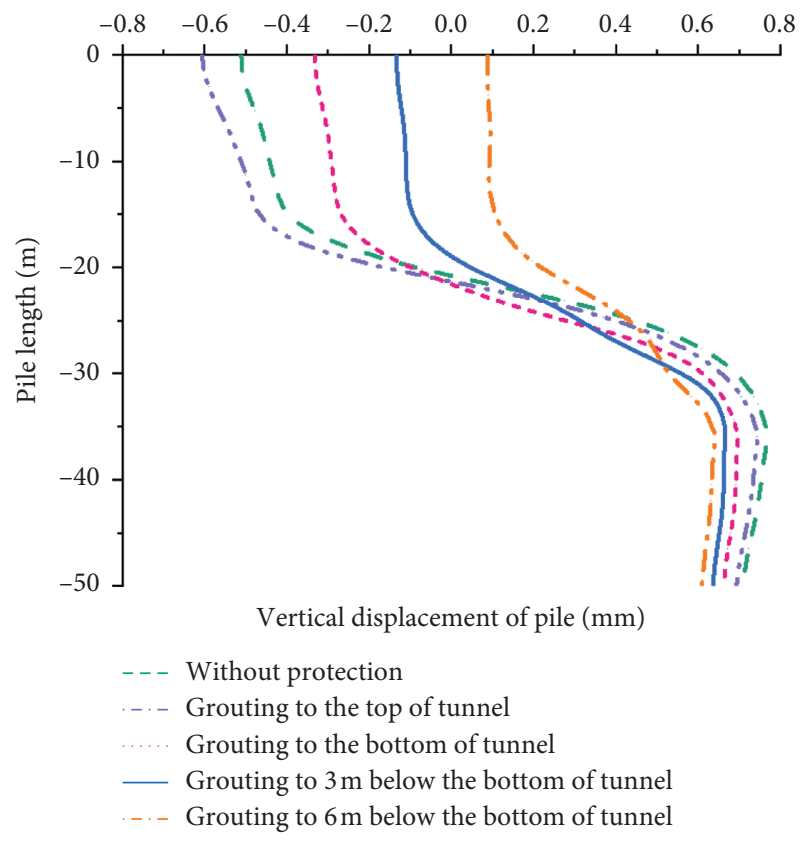

(a)

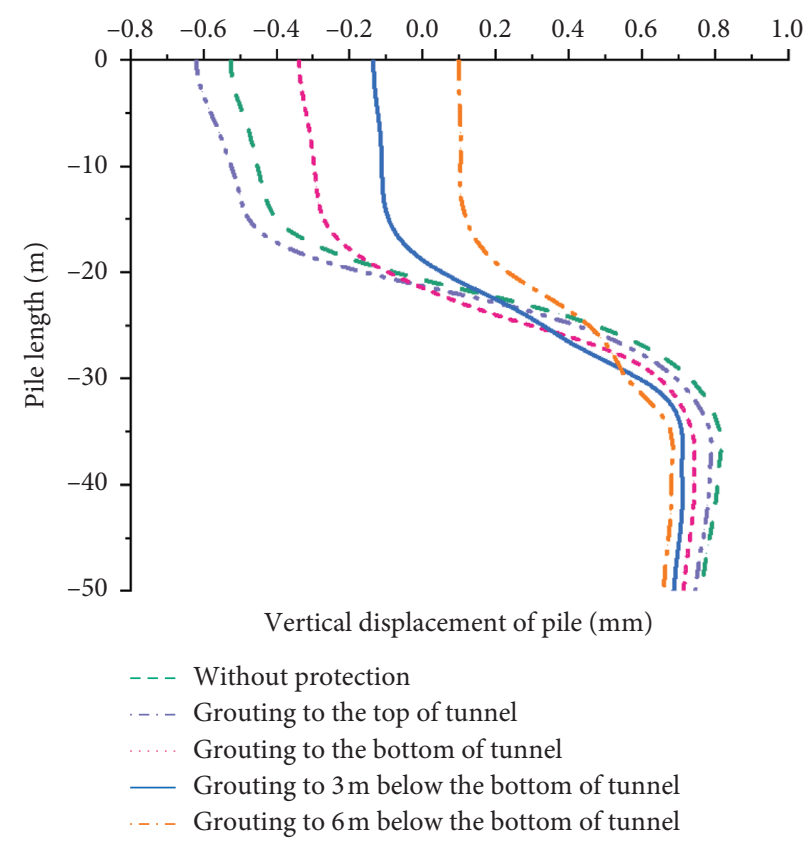

(b)

Figure 9: Vertical displacement of the pile: (a) 6 rings after passing the pile; (b) 8 rings after passing the pile.

displacement along the tunnel of the pile is investigated in the present study.

Shield tunneling machine requires a large thrust force, which makes the soil in front of the machine in compression and further leads to longitudinal displacement of the adjacent pile along the tunnel. During the process of the shield approaching the pile foundation, the pile will be deformed near the depth of the tunnel. When the excavation is close to the pile foundation, the deformation reaches the maximum value. When the grouting is not arranged, the maximum deformation of the pile is $1.41 \mathrm{~mm}$. After the shield passes through the pile foundation, the pile 


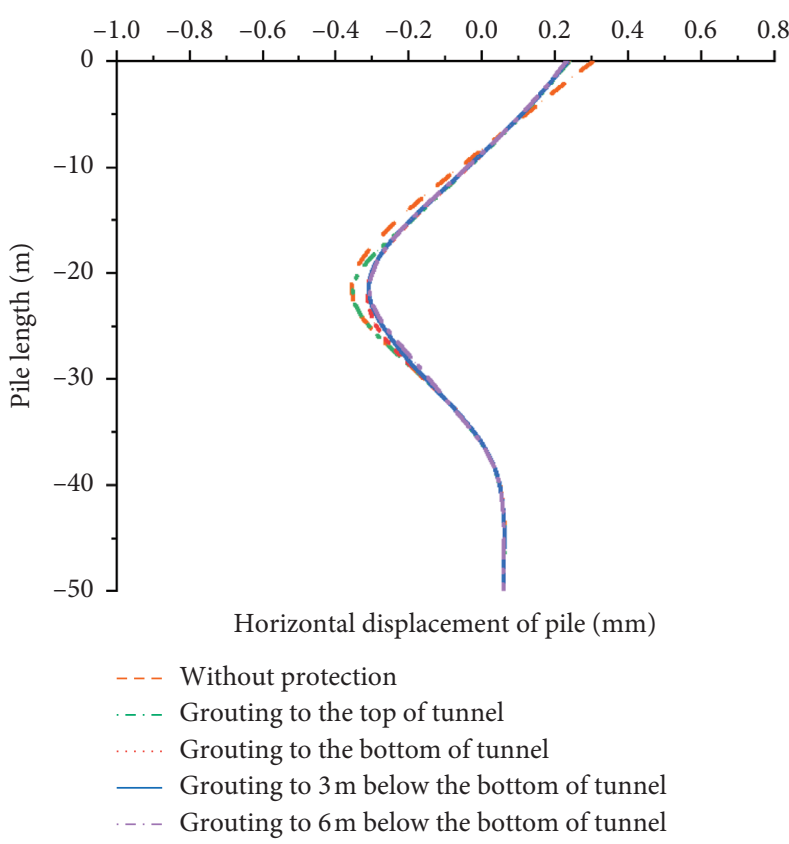

(a)

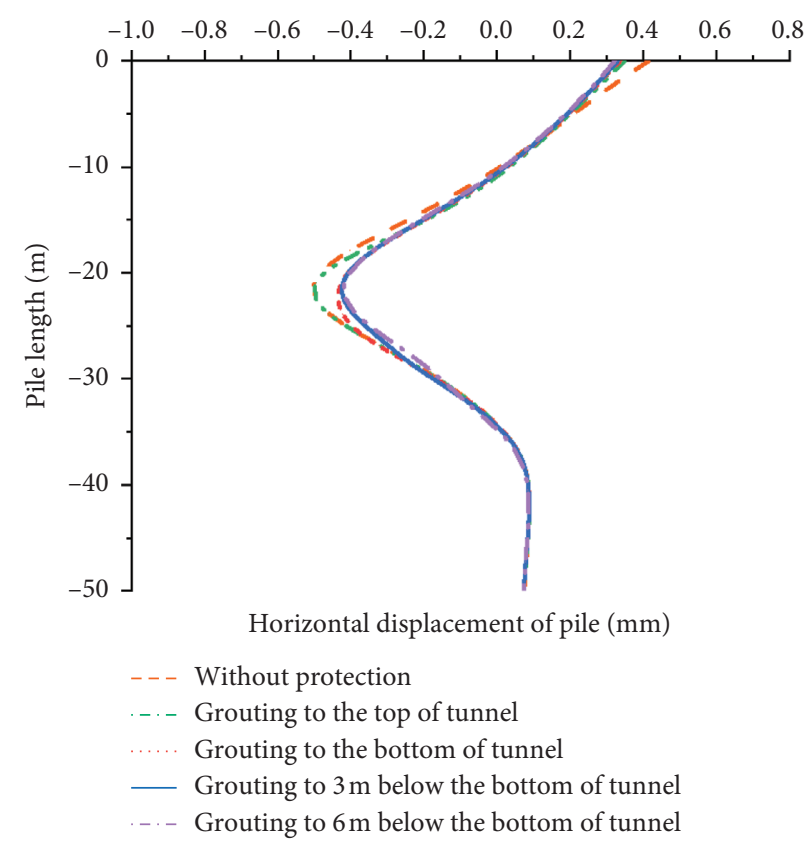

(b)

FIgURE 10: Horizontal displacement of the pile: (a) 6 rings before arriving at the pile; (b) 4 rings before arriving at the pile.

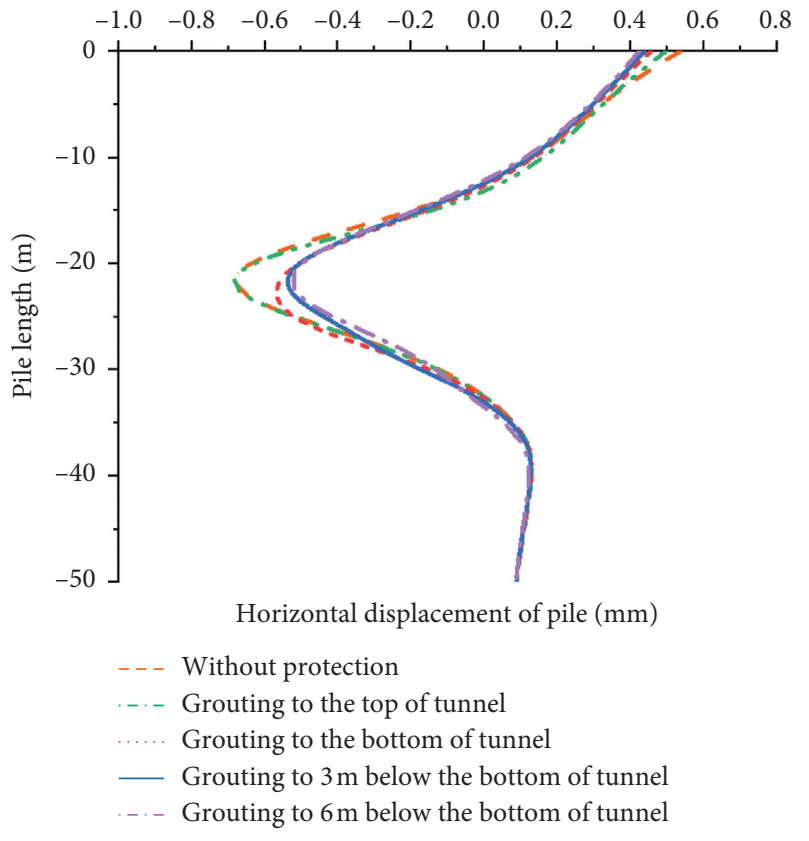

(a)

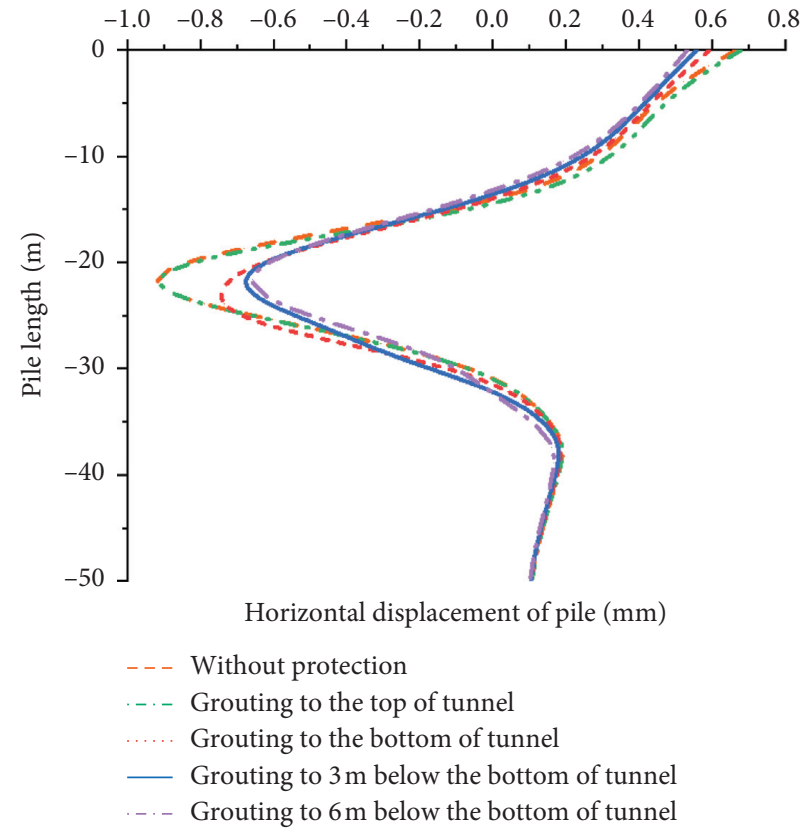

(b)

FIgURE 11: Horizontal displacement of the pile: (a) 2 rings before arriving at the pile; (b) arriving at the pile.

deformation will show a certain amount of rebound. As shown in Figures 14-18, grouting to the top of tunnel cannot control the longitudinal displacement of pile foundation. When grouting to the bottom of the tunnel, the longitudinal displacement of the pile along the tunnel is improved. The maximum displacement of the excavation plane at the nearest pile foundation is 3.74\% less than that without grouting. When the grouting reaches $3 \mathrm{~m}$ below the bottom of tunnel, the displacement of the pile along the longitudinal direction of the tunnel is further improved, and the maximum displacement is reduced by $10.11 \%$ compared with that without grouting. When the grouting 


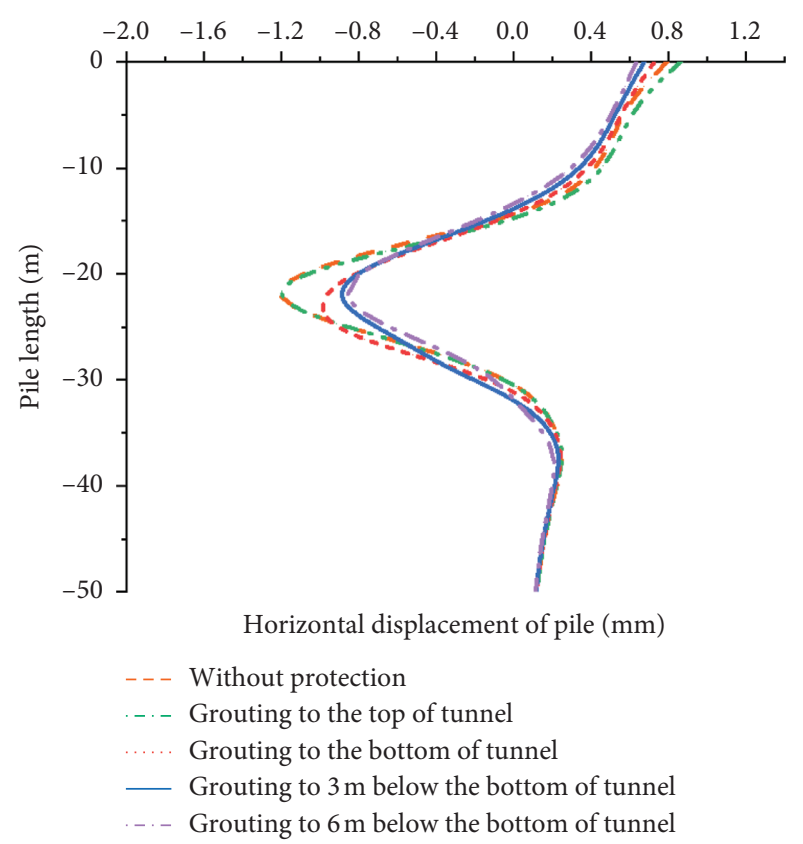

(a)

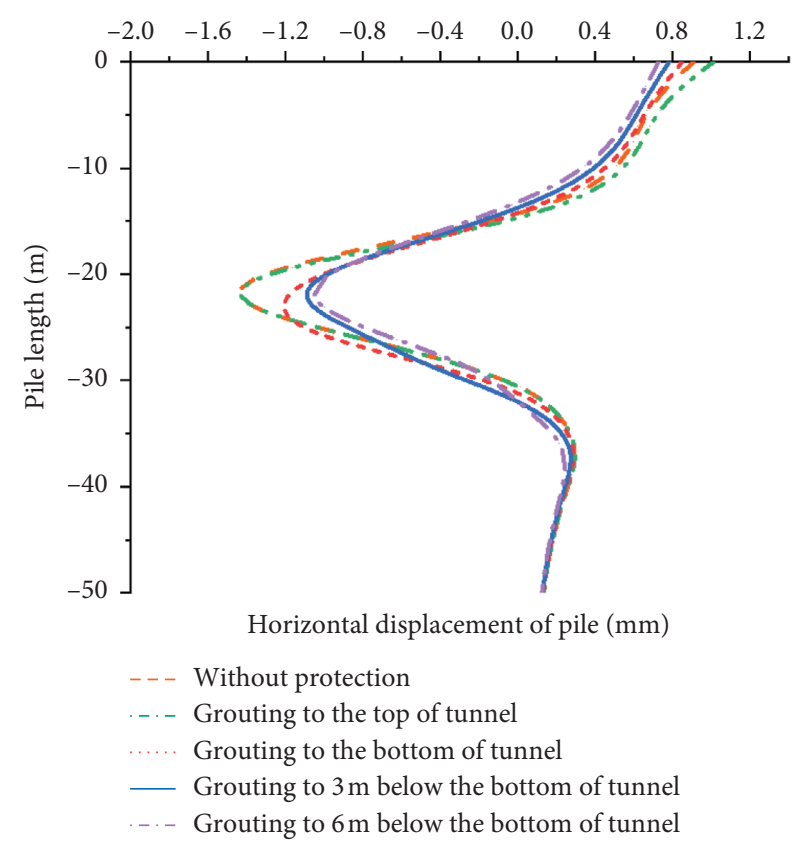

(b)

FIGURE 12: Horizontal displacement of the pile: (a) 2 rings after passing the pile; (b) 4 rings after passing the pile.

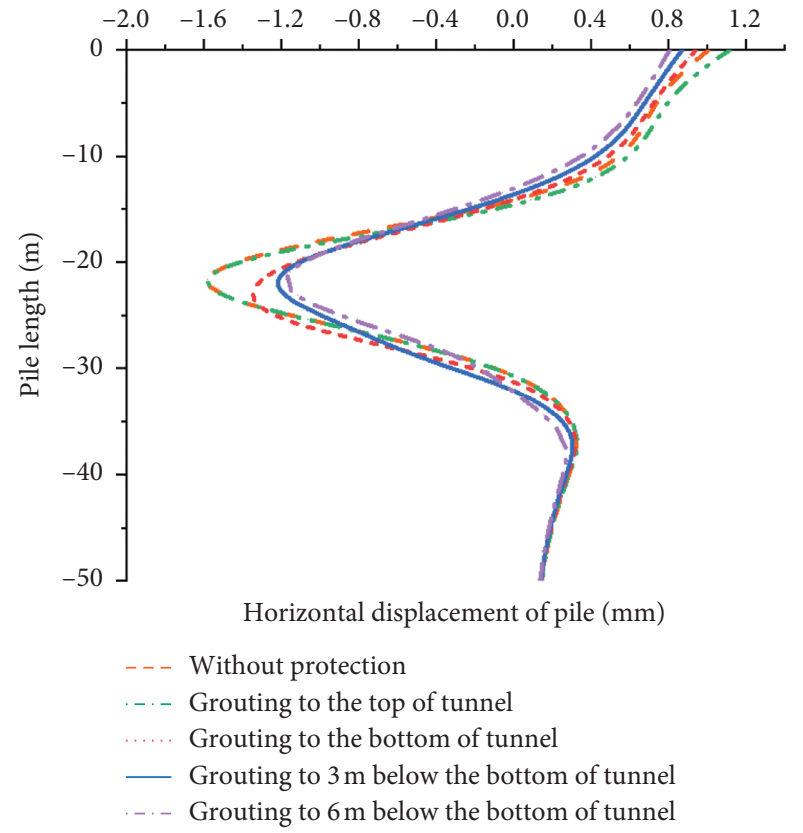

(a)

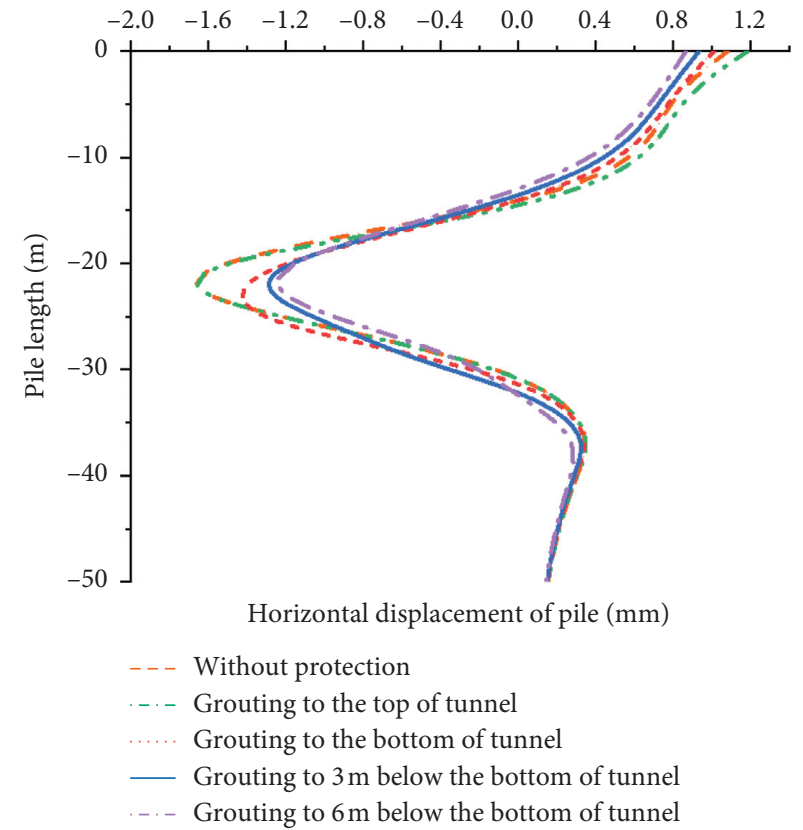

(b)

FIgURE 13: Horizontal displacement of the pile: (a) 6 rings after passing the pile; (b) 8 rings after passing the pile.

depth is further increased to $6 \mathrm{~m}$ below the tunnel, the maximum displacement is reduced by $13.86 \%$ compared with that without grouting. Although the control effect is enhanced to a certain extent, the cost of grouting will be increased. Therefore, it is better to set grouting isolation to $3 \mathrm{~m}$ below the tunnel.

\section{L-Shape Grouting Protection Wall}

In view of the fact that the longitudinal displacement of the pile along the tunnel cannot be ignored during shield tunneling, however, the horizontal grouting isolation scheme widely used in practical engineering has a slight 


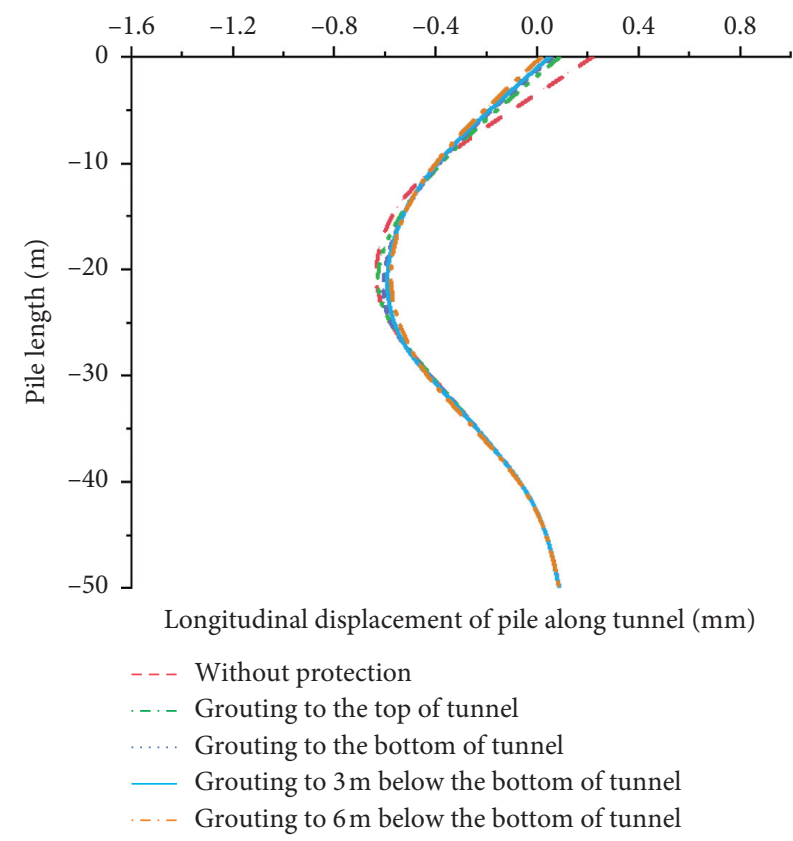

(a)

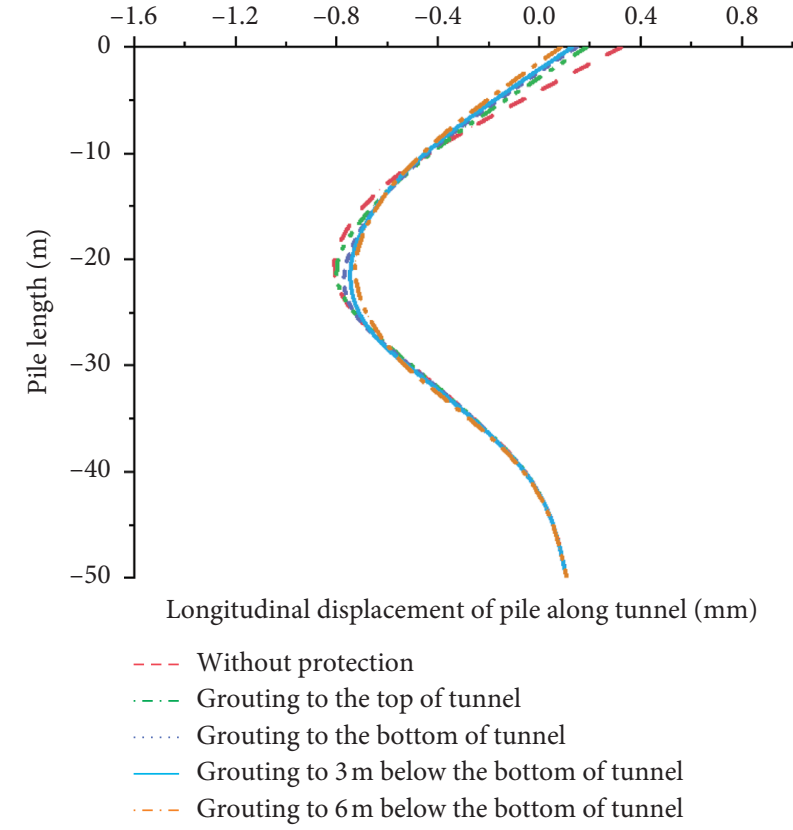

(b)

FIGURE 14: Longitudinal displacement of the pile along the tunnel: (a) 10 rings before arriving at the pile; (b) 8 rings before arriving at the pile.

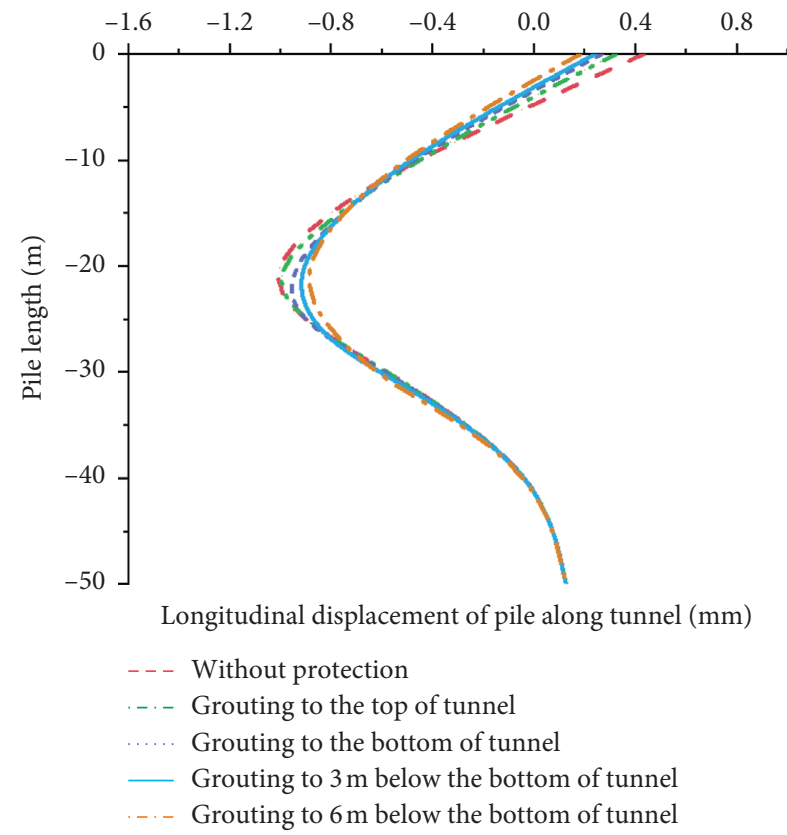

(a)

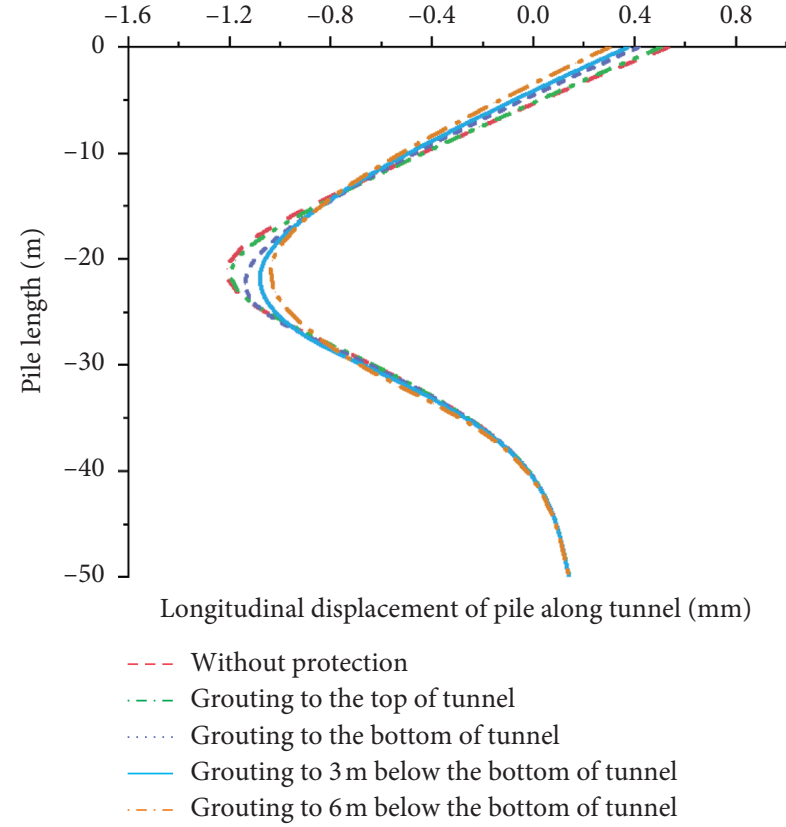

(b)

FIGURE 15: Longitudinal displacement of the pile along the tunnel: (a) 6 rings before arriving at the pile; (b) 4 rings before arriving at the pile.

effect on the controlling of longitudinal deformation of the pile along the tunnel. Therefore, an "L"- shape grouting protection wall is proposed, as shown in Figure 19. By setting a semienclosed grouting isolation, the vertical and horizontal displacement of the pile foundation can be effectively reduced, and the longitudinal displacement along the tunnel caused by tunneling pressure can be decreased during the process of shield tunneling.
According to the results mentioned above, when the grouting depth is $3 \mathrm{~m}$ below the tunnel, both vertical and horizontal displacement of the pile foundation was significantly decreased. Therefore, the traditional grouting scheme and the proposed L-shaped grouting scheme are compared when the grouting depth is $3 \mathrm{~m}$ below the tunnel. The finite element model of the L-shaped grouting scheme is shown in Figure 20. 


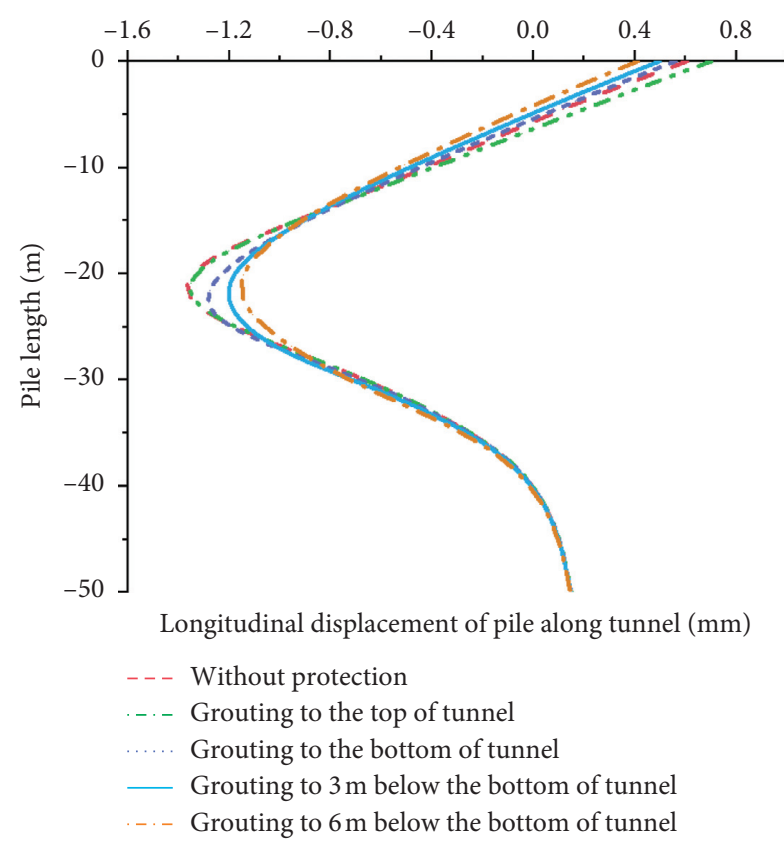

(a)

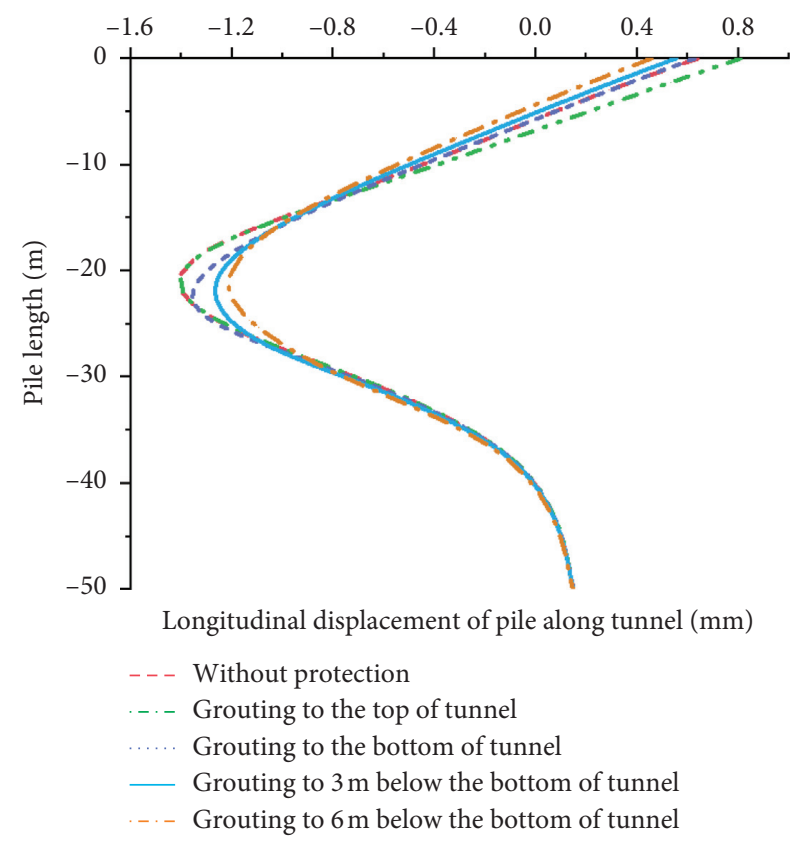

(b)

Figure 16: Longitudinal displacement of the pile along the tunnel: (a) 2 rings before arriving at the pile; (b) arriving at the pile.

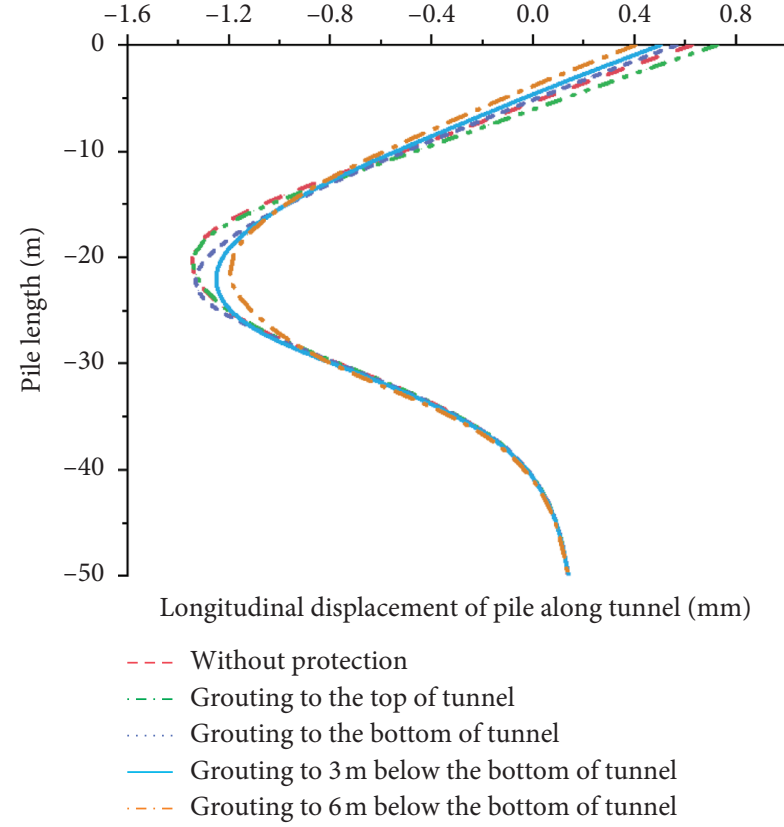

(a)

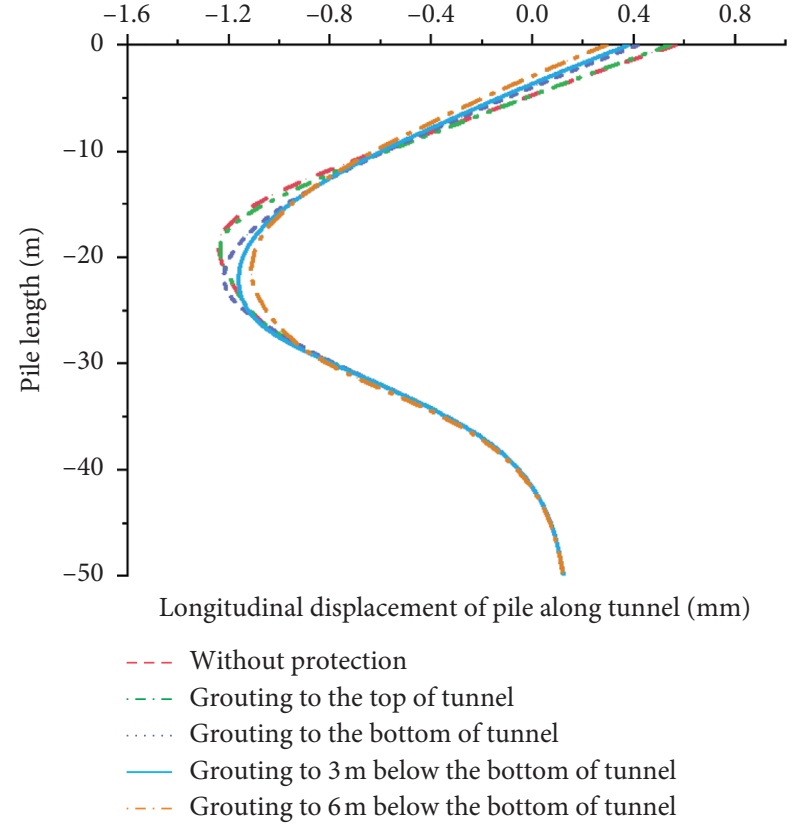

(b)

FIgURE 17: Longitudinal displacement of the pile along the tunnel: (a) 2 rings after passing the pile; (b) 4 rings after passing the pile.

6.1. Comparison of Longitudinal Displacement of the Pile along the Tunnel. Figures 21-24 show the comparison of longitudinal displacement of the pile using I-shape and L-shape grouting isolation protection schemes during the tunnel construction process. Compared with the traditional parallel grouting scheme, the L-shaped grouting scheme can effectively reduce the longitudinal displacement of the pile along the tunnel. When the shield excavates to the nearest position of the pile foundation, the displacement at the top of the pile decreased by $31.49 \%$, and the maximum 


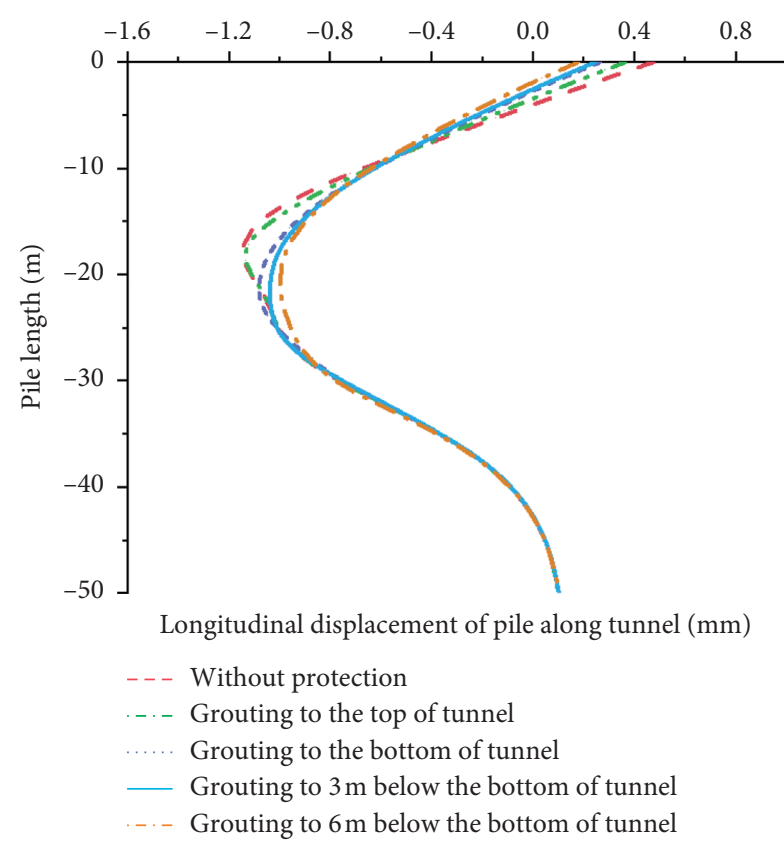

(a)

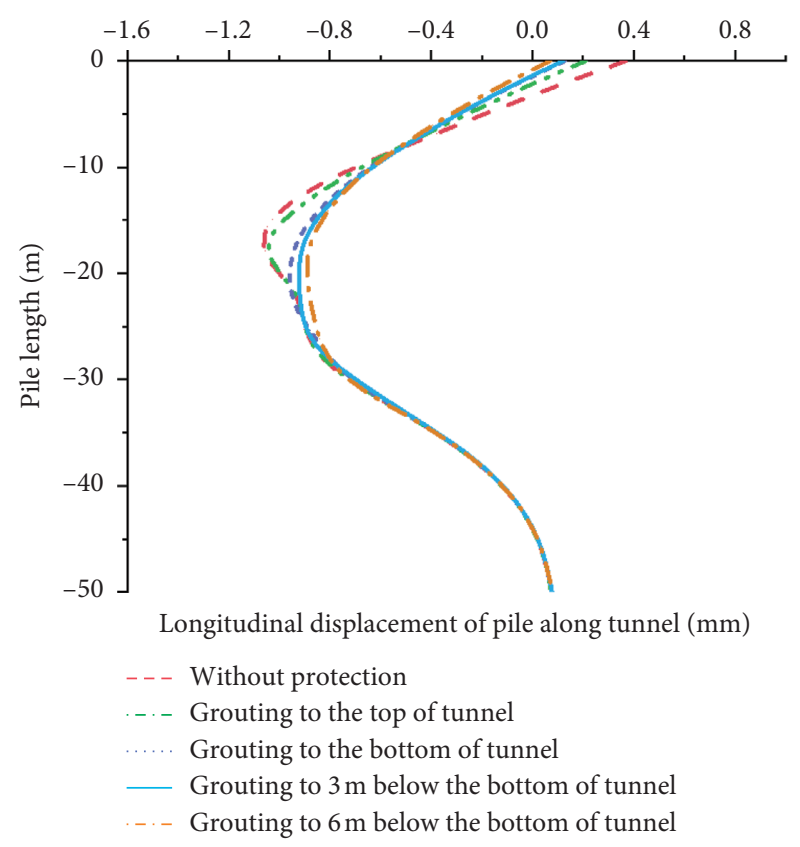

(b)

FIGURE 18: Longitudinal displacement of the pile along the tunnel: (a) 6 rings after passing the pile; (b) 8 rings after passing the pile.
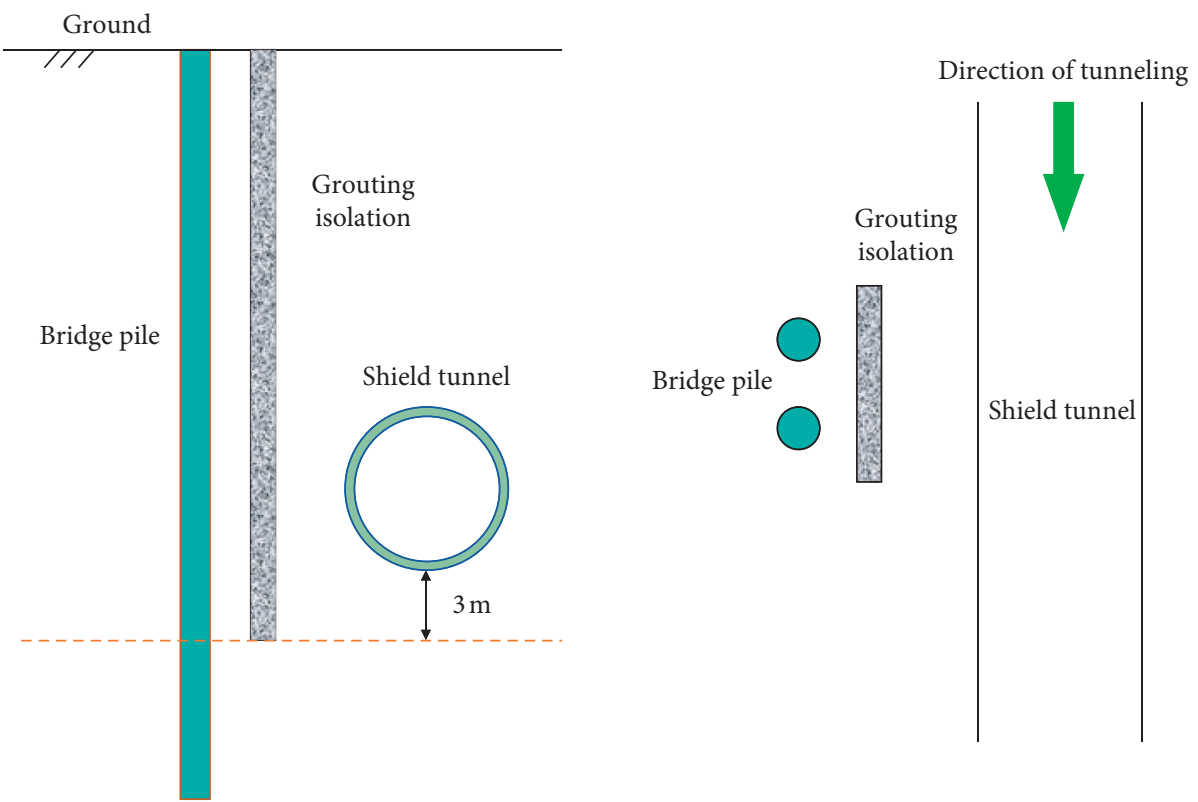

(a)

FIgURE 19: Continued. 


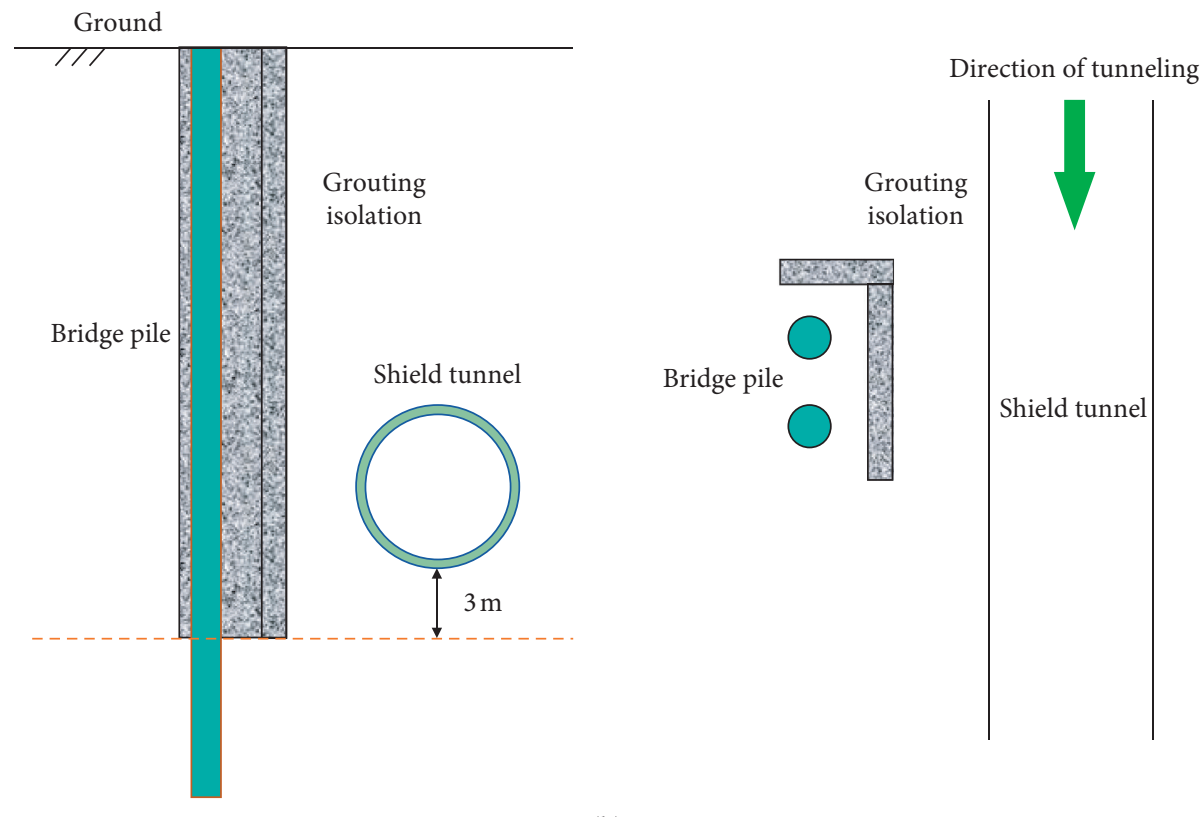

(b)

FIGURE 19: Grouting scheme comparison: (a) traditional parallel grouting; (b) L-type optimized grouting.
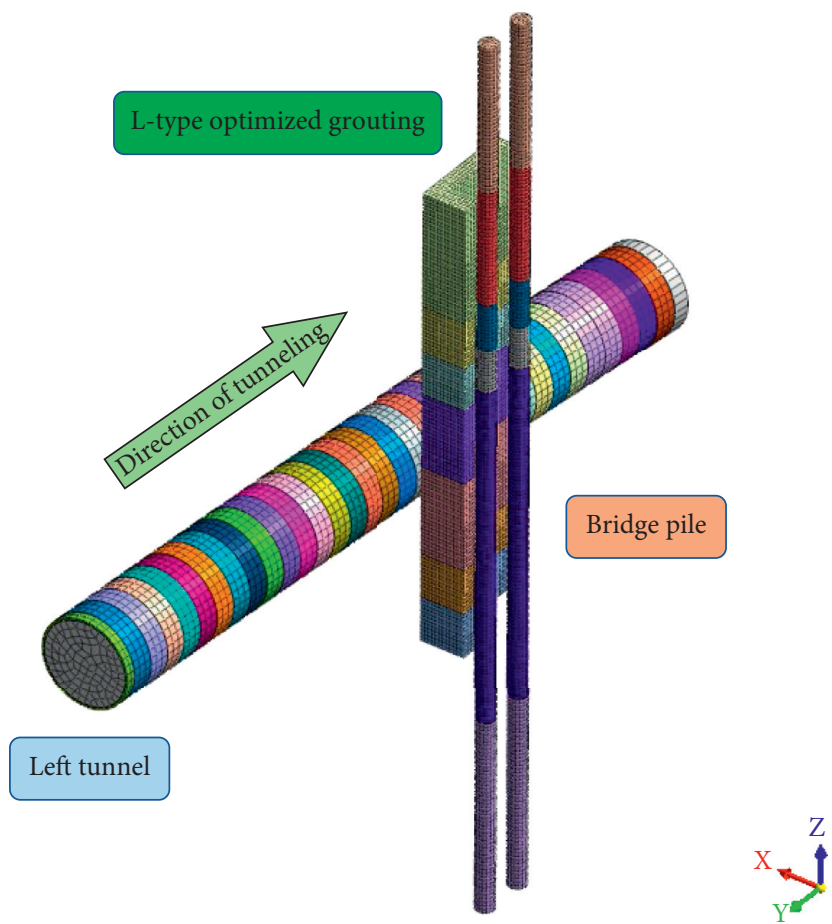

Figure 20: Finite element model of the L-shaped grouting wall.

deformation reduced by $3.73 \%$. After shield tunneling passes through the pile, the longitudinal displacement of the pile began to rebound due to the absence of the driving pressure from the excavation plane. When shield tunneling passes through 6 rings of pile foundation, the maximum displacement of the pile using the L-shape grouting scheme is $0.967 \mathrm{~mm}$, while that using the traditional I-shape grouting scheme is $1.037 \mathrm{~mm}$, which is reduced by $6.75 \%$. 


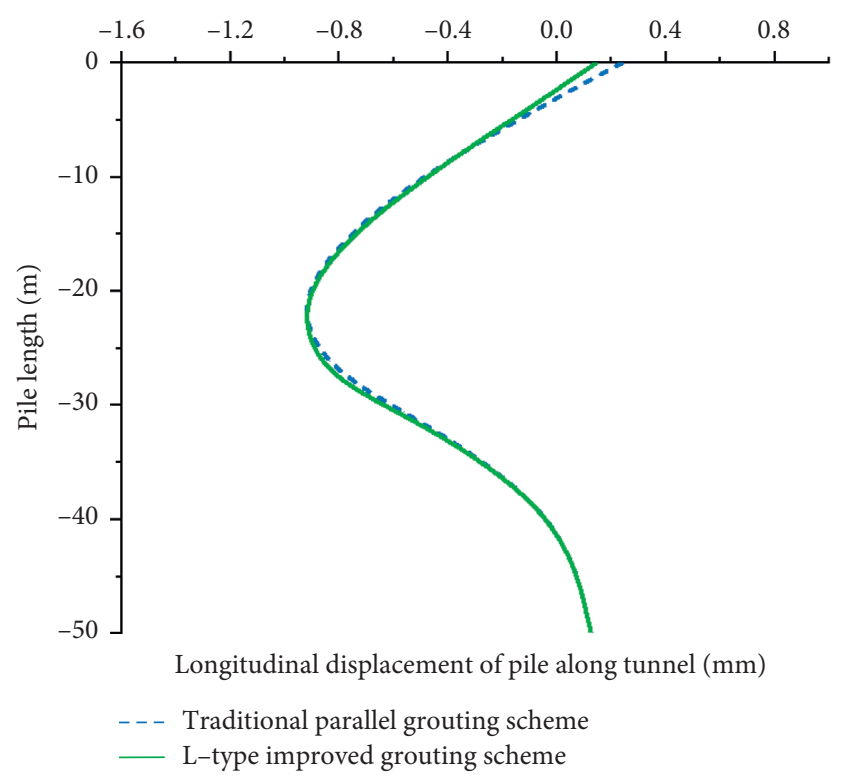

(a)

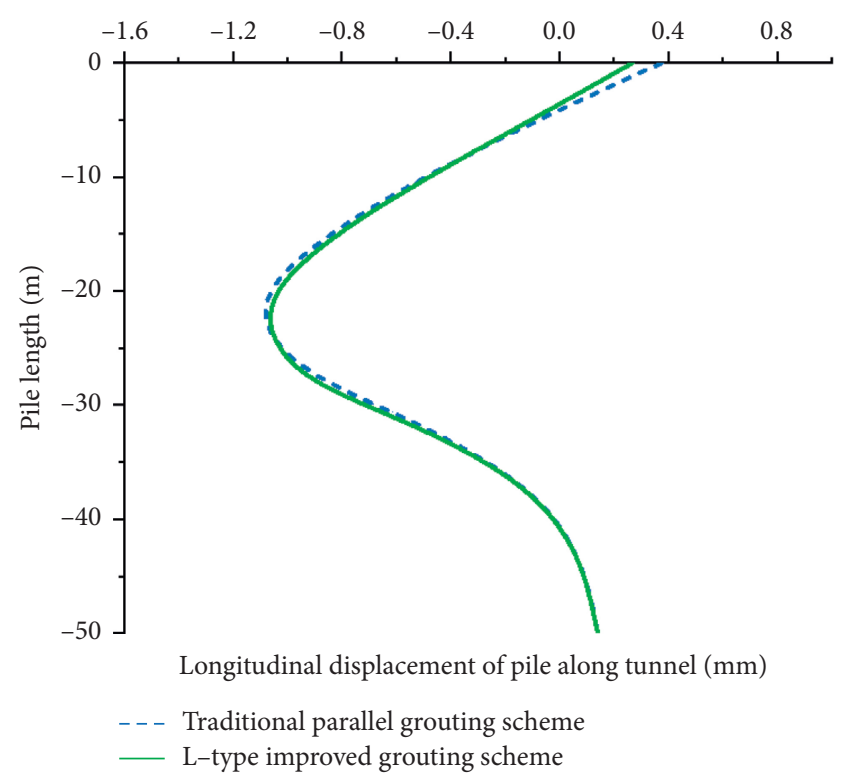

(b)

Figure 21: Longitudinal displacement of the pile along tunnel: (a) 6 rings before arriving at the pile; (b) 4 rings before arriving at the pile.

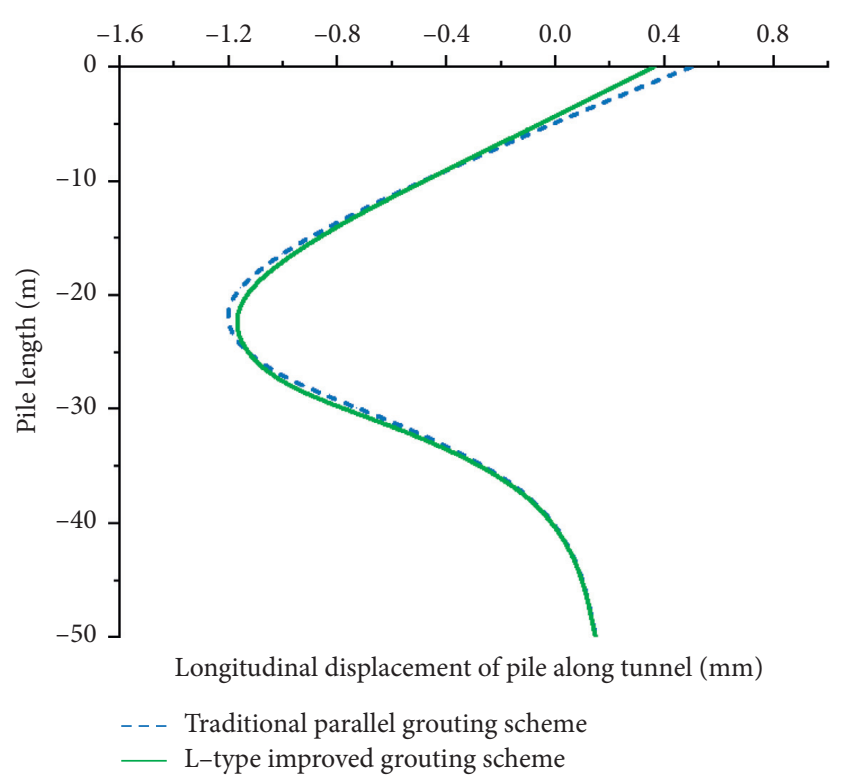

(a)

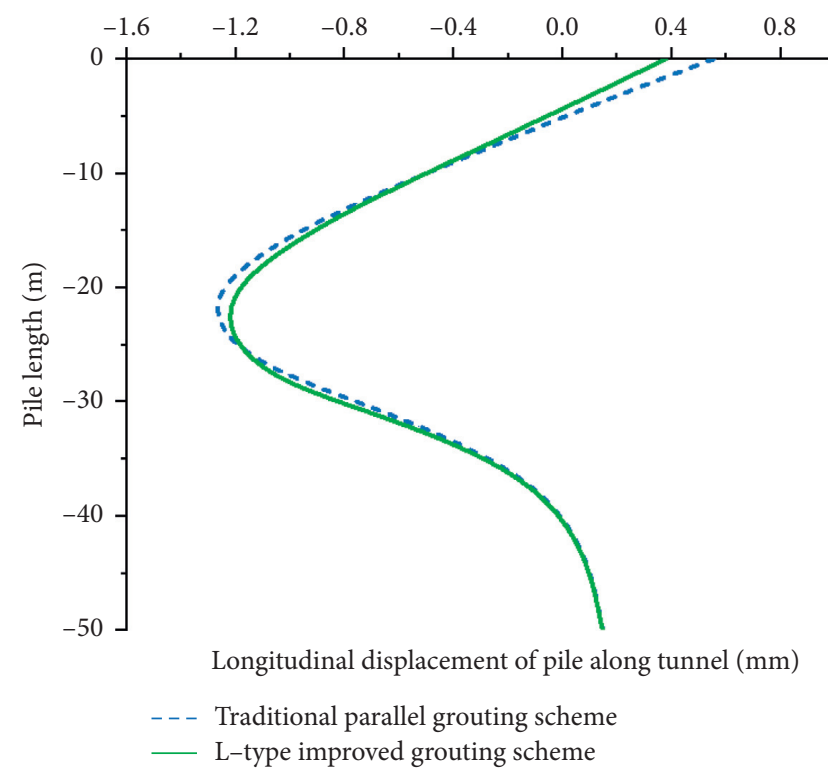

(b)

FIGURE 22: Longitudinal displacement of the pile along tunnel: (a) 2 rings before arriving at the pile; (b) arriving at the pile.

When the shield tunneling passes through 8 rings of the pile foundation, the maximum displacement of the pile using the L-shape grouting scheme is $0.855 \mathrm{~mm}$, while the maximum displacement of the pile using the traditional I-shape grouting scheme is $0.917 \mathrm{~mm}$, reduced by $6.76 \%$.
Because the "L"-shape grouting wall has a certain ability to resist the pressure of shield tunneling, therefore, the optimized L-shape grouting scheme can reduce the longitudinal displacement of the pile along the tunnel during shield construction. 


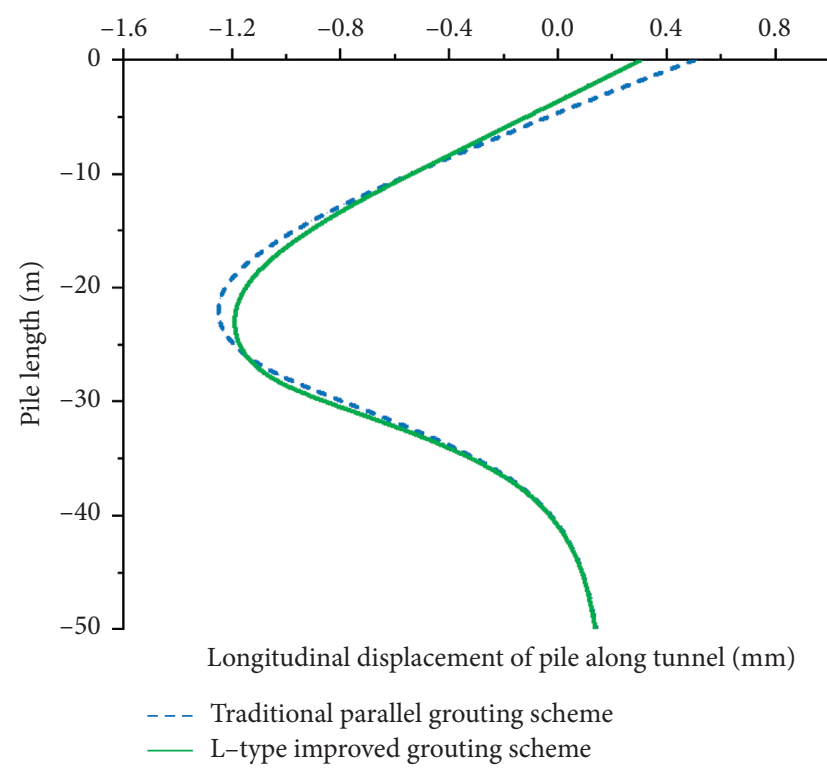

(a)

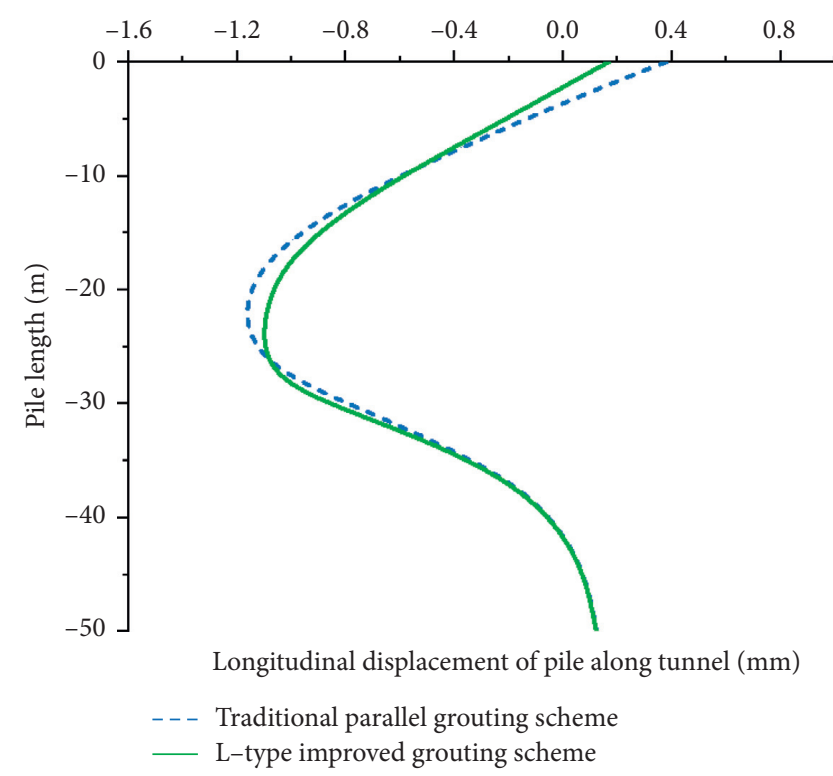

(b)

FIGURE 23: Longitudinal displacement of the pile along tunnel: (a) 2 rings after passing the pile; (b) 4 rings after passing the pile.

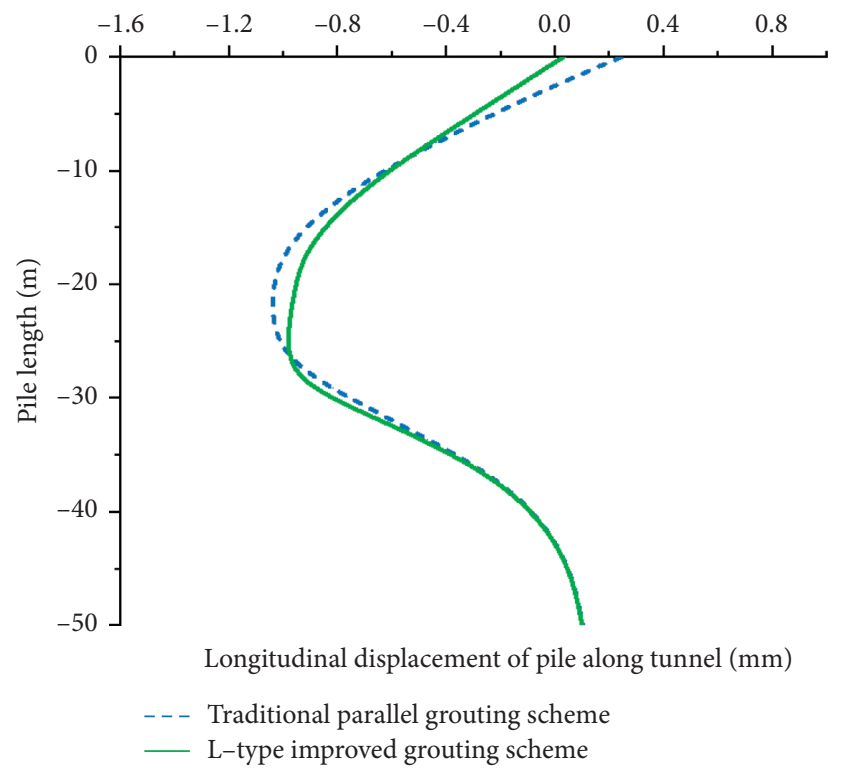

(a)

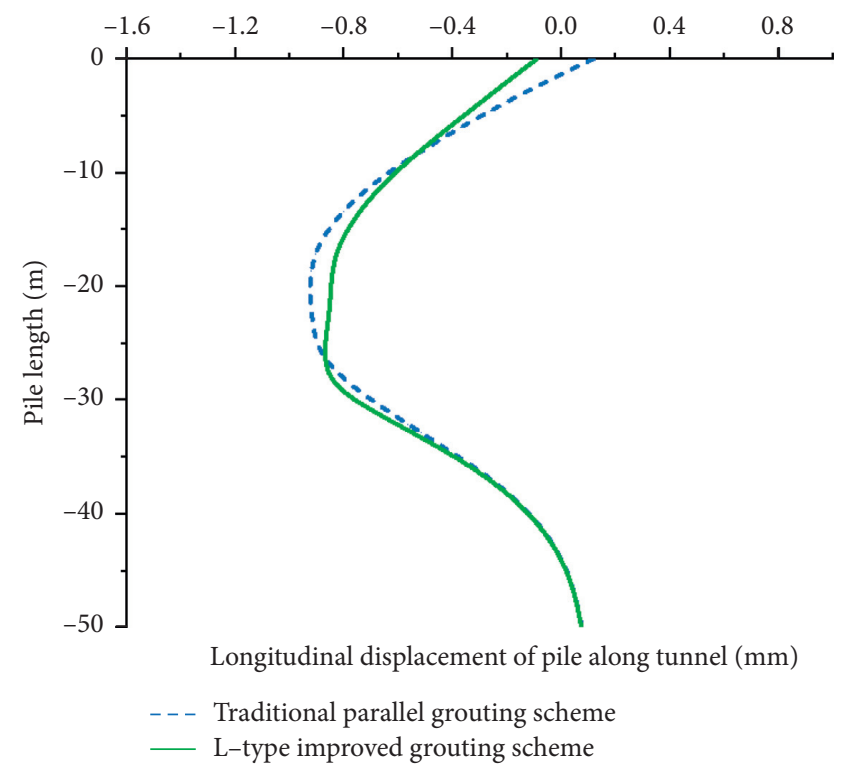

(b)

FIgURE 24: Longitudinal displacement of the pile along tunnel: (a) 6 rings after passing the pile; (b) 8 rings after passing the pile.

\section{Conclusions}

This paper presents finite element analyses on the deformation of bridge pile using the grouting protection wall with different depths and shapes when shield tunnel is under construction. The main conclusions are drawn as follows:

(1) During the process of shield tunneling through viaduct piles, both vertical and horizontal displacements of piles show an increasing trend. The increase rate decreases after the shield passes through the pile foundation and is basically stable at the $8^{\text {th }}$ ring position after the shield passes through the pile foundation. The longitudinal displacement of the pile along the tunnel increases first and then decreases, and the maximum value appears when the shield tunneling is close to the pile foundation. After the shield passes through the pile foundation, the longitudinal displacement of the pile rebounds to a certain extent.

(2) By comparing the effect on pile foundation under four different grouting depths, it can be found that 
grouting to the top of the tunnel cannot control the displacement or even aggravate the displacement of pile foundation. Grouting to the bottom of the tunnel can play a certain role in improving the pile foundation, but the improvement is not obvious. The displacement of the pile foundation when grouting to $3 \mathrm{~m}$ below the tunnel bottom is obviously reduced. If the grouting depth is further increased to $6 \mathrm{~m}$ below the bottom of the tunnel, the improvement is limited compared with that of $3 \mathrm{~m}$ below the bottom of the tunnel. Therefore, considering the grouting effect and construction cost, the grouting depth is determined as $3 \mathrm{~m}$ below the bottom of the tunnel.

(3) The longitudinal deformation of the pile foundation along the tunnel is mainly depending on the thrust force of the shield. An "L"-shape grouting wall was proposed and confirmed effectively reducing the longitudinal deformation of the pile. The present findings may provide a reference for the design and construction of shield tunnel passing through viaduct piles.

\section{Data Availability}

The data used to support the findings of this study are available from the corresponding author upon request.

\section{Conflicts of Interest}

The authors declare that there are no conflicts of interest regarding the publication of this paper.

\section{Acknowledgments}

This work was supported by the National Natural Science Foundation of China (52078060), the National Science Foundation of Hunan Province (2020JJ4606), the Key Foundation of Education Department of Hunan Province (18A127), and the International Cooperation and Development Project of Double-First-Class Scientific Research in Changsha University of Science and Technology (2018IC19).

\section{References}

[1] R. B. Peck, "Deep excavations and tunneling in soft ground," in Proceedings of the 7th International Conference on Soil Mechanics and Foundation Engineering, pp. 192-201, Mexico City, Mexico, 1969.

[2] G. W. Clough and B. Schmidt, "Design and performance of excavations and tunnels in soft clay," Elsevier Science Publishing Company, vol. 20, pp. 569-634, 1981.

[3] P. B. Attewell and J. P. Woodman, "Predicting the dynamics of ground settlement and its derivatives caused by tunneling in soil," Ground Engineering, vol. 15, no. 8, pp. 13-36, 1982.

[4] M. P. O’Reilly and B. M. New, "Settlements above tunnels in the United Kingdom - their magnitude and prediction," in Proceedings of the Tunnelling'82 symposium, Institution of Mining and Metallurgy, pp. 173-181, London, 1982.

[5] N. Loganathan and H. G. Poulos, "Analytical prediction for tunneling-induced ground movements in clays," Journal of
Geotechnical and Geoenvironmental Engineering, vol. 124, no. 9, pp. 846-856, 1998.

[6] X.-f. Li, S.-j. Du, and B. Chen, "Unified analytical solution for deep circular tunnel with consideration of seepage pressure, grouting and lining," Journal of Central South University, vol. 24, no. 6, pp. 1483-1493, 2017.

[7] X. M. Zhang, X. F. Ou, J. S. Yang, and J. Y. Fu, "Deformation response of an existing tunnel to upper excavation of foundation pit and associated dewatering," International Journal of Geomechanics, vol. 17, no. 4, 14 pages, Article ID 04016112, 2017.

[8] W.-C. Cheng, Z.-P. Song, W. Tian, and Z.-F. Wang, "Shield tunnel uplift and deformation characterisation: a case study from Zhengzhou metro," Tunnelling and Underground Space Technology, vol. 79, pp. 83-95, 2018.

[9] Z. Li, Z. Luo, C. Xu, and J. Tan, "3D fluid-solid full coupling numerical simulation of soil deformation induced by shield tunnelling," Tunnelling and Underground Space Technology, vol. 90, pp. 174-182, 2019.

[10] Y. Su, Y. Su, M. Zhao, and N. Vlachopoulos, "Tunnel stability analysis in weak rocks using the convergence confinement method," Rock Mechanics and Rock Engineering, vol. 54, no. 2, pp. 559-582, 2021.

[11] M. Nematollahi and D. Dias, "Three-dimensional numerical simulation of pile-twin tunnels interaction - case of the Shiraz subway line," Tunnelling and Underground Space Technology, vol. 86, pp. 75-88, 2019.

[12] H. Sun, Q. Wang, P. Zhang, Y. Zhong, and X. Yue, "Spatialtemporal characteristics of tunnel traffic accidents in China from 2001 to present," Advances in Civil Engineering, vol. 2019, Article ID 4536414, 12 pages, 2019.

[13] X. Liu, Q. Fang, D. Zhang, and Z. Wang, "Behaviour of existing tunnel due to new tunnel construction below," Computers and Geotechnics, vol. 110, pp. 71-81, 2019.

[14] Z. Ding, X. Wei, X. Zhang, and X. Yin, "Analysis of the field monitoring data on soil movements and adjacent building settlement due to shield tunnelling," Engineering Computations, vol. 36, no. 4, pp. 1219-1237, 2019.

[15] T. Liu, Y. Zhong, Z. Feng, W. Xu, and F. Song, "New construction technology of a shallow tunnel in boulder-cobble mixed grounds," Advances in Civil Engineering, vol. 2020, Article ID 5686042, 14 pages, 2020.

[16] Y.-l. An, J. Zhou, P.-b. Ouyang, and J.-h. Li, "Analysis of tunnel face stability with advanced pipes support," Journal of Central South University, vol. 28, no. 2, pp. 604-617, 2021.

[17] Z. Zhang, W. Li, and J. Yang, "Analysis of stochastic process to model safety risk in construction industry," Journal of Civil Engineering and Management, vol. 27, no. 2, pp. 87-99, 2021.

[18] C. Q. Liu, D. J. Fang, and Z. X. Yan, "Seismic fragility analysis of base isolated structure subjected to near-fault ground motions," Periodica Polytechnica: Civil Engineering, vol. 65, no. 3, pp. 768-783, 2021.

[19] M.-h. Zhao, D.-p. Liu, L. Zhang, and C. Jiang, "3D finite element analysis on pile-soil interaction of passive pile group," Journal of Central South University of Technology, vol. 15, no. 1, pp. 75-80, 2008.

[20] M. Yang, Q. Sun, W.-c. Li, and K. Ma, “Three-dimensional finite element analysis on effects of tunnel construction on nearby pile foundation," Journal of Central South University, vol. 18, no. 3, pp. 909-916, 2011.

[21] P. Jongpradist, T. Kaewsri, A. Sawatparnich et al., "Development of tunneling influence zones for adjacent pile foundations by numerical analyses," Tunnelling and Underground Space Technology, vol. 34, pp. 96-109, 2013. 
[22] G. Meschke, J. Ninić, J. Stascheit, and A. Alsahly, "Parallelized computational modeling of pile-soil interactions in mechanized tunneling," Engineering Structures, vol. 47, pp. 35-44, 2013.

[23] D. S. Liyanapathirana and R. Nishanthan, "Influence of deep excavation induced ground movements on adjacent piles," Tunnelling and Underground Space Technology, vol. 52, pp. 168-181, 2016.

[24] K. Zhao, S. J. Du, J. Chen, and H. F. Nan, "Numerical analysis on small disturbance control in shield crossing the piles of bridge," Chinese Journal of Underground Space and Engineering, vol. 13, no. 6, pp. 1609-1615, 2017, in Chinese.

[25] H. Yu, C. Cai, Y. Yuan, and M. Jia, "Analytical solutions for Euler-Bernoulli Beam on Pasternak foundation subjected to arbitrary dynamic loads," International Journal for Numerical and Analytical Methods in Geomechanics, vol. 41, no. 8, pp. 1125-1137, 2017.

[26] H. Lin, X. Zhang, R. H. Cao, and Z. J. Wen, "Improved nonlinear Burgers shear creep model based on the time-dependent shear strength for rock," Environmental Earth Sciences, vol. 79, Article ID 149, 2020.

[27] S. Li, L. Wei, X. Chen, and Q. He, "Numerical investigation on dynamic performance of a bridge-tunnel transition section with a deep buried pile-plank structure," Advances in Civil Engineering, vol. 2020, Article ID 8885535, 16 pages, 2020.

[28] K. Huang, Y.-W. Sun, X.-Q. Huang, Y.-J Li, M. Jiang, and R.-N Liu, "Effects of different construction sequences on ground surface settlement and displacement of single long pile due to twin paralleled shield tunneling," Advances in Civil Engineering, vol. 2021, Article ID 5559233, 14 pages, 2021.

[29] K. Huang, Y.-W. Sun, D.-Q Zhou, Y.-J Li, M. Jiang, and X.-Q. Huang, "Influence of water-rich tunnel by shield tunneling on existing bridge pile foundation in layered soils," Journal of Central South University, vol. 28, no. 8, 15 pages, 2021.

[30] D. R. Coutts and J. Wang, "Monitoring of reinforced concrete piles under horizontal and vertical loads due to tunneling," in Proceedings of the International Conference on Tunnels and Underground Structures, pp. 514-546, Balkma, Singapore, November 2000.

[31] A. Sirivachiraporn and N. Phienwej, "Ground movements in EPB shield tunneling of Bangkok subway project and impacts on adjacent buildings," Tunnelling and Underground Space Technology, vol. 30, pp. 10-24, 2012.

[32] C. W. W. Ng, H. Lu, and S. Y. Peng, "Three-dimensional centrifuge modelling of the effects of twin tunnelling on an existing pile," Tunnelling and Underground Space Technology, vol. 35, pp. 189-199, 2013.

[33] T. Boonyarak, K. Phisitkul, C. W. W. Ng, W. Teparaksa, and Z. Z. Aye, "Observed ground and pile group responses due to tunneling in Bangkok stiff clay," Canadian Geotechnical Journal, vol. 51, no. 5, pp. 479-495, 2014.

[34] Q. Xu, H. Zhu, X. Ma et al., "A case history of shield tunnel crossing through group pile foundation of a road bridge with pile underpinning technologies in Shanghai," Tunnelling and Underground Space Technology, vol. 45, pp. 20-33, 2015.

[35] H. Khabbaz, R. Gibson, and B. Fatahi, "Effect of constructing twin tunnels under a building supported by pile foundations in the Sydney central business district," Underground Space, vol. 4, no. 4, pp. 261-276, 2019.

[36] H. Zhao, J. Zhang, P. Qiu, and S. Ji, "Hierarchical modeling method for DEM simulation and its application in soil-pilecap interaction and impact case," International Journal of Geomechanics, vol. 19, no. 7, Article ID 04019076, 2019.
[37] Y. Zhou, G. Kong, Q. Yang, and H. Li, "Deformation analysis of geosynthetic-encased stone column using cavity expansion models with emphasis on boundary condition," Geotextiles and Geomembranes, vol. 47, no. 6, pp. 831-842, 2019.

[38] B. Y. Zhao, X. P. Wang, C. Zhang, W. C. Li, R. Abbassi, and K. Chen, "Structural integrity assessment of shield tunnel crossing of a railway bridge using orthogonal experimental design," Engineering Failure Analysis, vol. 2020, Article ID 104594, 2020.

[39] L. Mu, M. Huang, and R. J. Finno, "Tunnelling effects on lateral behavior of pile rafts in layered soil," Tunnelling and Underground Space Technology, vol. 28, pp. 192-201, 2012.

[40] C. Liu, Z. Zhang, and R. A. Regueiro, "Pile and pile group response to tunnelling using a large diameter slurry shield case study in Shanghai," Computers and Geotechnics, vol. 59, pp. 21-43, 2014.

[41] Y. Hong, M. A. Soomro, and C. W. W. Ng, "Settlement and load transfer mechanism of pile group due to side-by-side twin tunnelling," Computers and Geotechnics, vol. 64, pp. 105-119, 2015.

[42] M. A. Soomro, Y. Hong, C. W. W. Ng, H. Lu, and S. Peng, "Load transfer mechanism in pile group due to single tunnel advancement in stiff clay," Tunnelling and Underground Space Technology, vol. 45, pp. 63-72, 2015.

[43] Z.-G. Zhang, C. Xu, and J.-F. Gong, "Influence of tunneling on deflection of adjacent piles considering shearing deformation of foundation and 3D effects of lateral soils beside piles," Chinese Journal of Geotechnical Engineering, vol. 38, no. 5, pp. 846-856, 2016, in Chinese.

[44] M. A. Soomro, C. W. W. Ng, K. Liu, and N. A. Memon, "Pile responses to side-by-side twin tunnelling in stiff clay: effects of different tunnel depths relative to pile," Computers and Geotechnics, vol. 84, pp. 101-116, 2017.

[45] Z. Zhang, M. Huang, C. Xu, Y. Jiang, and W. Wang, "Simplified solution for tunnel-soil-pile interaction in Pasternak's foundation model," Tunnelling and Underground Space Technology, vol. 78, pp. 146-158, 2018.

[46] Z.-F. Wang, S.-L. Shen, and G. Modoni, "Enhancing discharge of spoil to mitigate disturbance induced by horizontal jet grouting in clayey soil: theoretical model and application," Computers and Geotechnics, vol. 111, pp. 222-228, 2019.

[47] Y. Xiang, Z. Jiang, and H. He, "Assessment and control of metro-construction induced settlement of a pile-supported urban overpass," Tunnelling and Underground Space Technology, vol. 23, no. 3, pp. 300-307, 2008.

[48] A. Kirsch and L. Piazzi, "Numerical investigation of the effectiveness of a bored pile wall for the minimisation of settlement resulting from tunnel driving," Geomechanik und Tunnelbau, vol. 2, no. 6, pp. 753-765, 2010.

[49] E. Bilotta and G. Russo, "Use of a line of piles to prevent damages induced by tunnel excavation," Journal of Geotechnical and Geoenvironmental Engineering, vol. 137, no. 3, pp. 254-262, 2011.

[50] Y. Bai, Z. Yang, and Z. Jiang, "Key protection techniques adopted and analysis of influence on adjacent buildings due to the Bund Tunnel construction," Tunnelling and Underground Space Technology, vol. 41, pp. 24-34, 2014.

[51] J.-Y. Fu, J.-S. Yang, S.-T. Zhu, and Y.-F. Shi, "Performance of jet-grouted partition walls in mitigating the effects of shieldtunnel construction on adjacent piled structures," Journal of Performance of Constructed Facilities, vol. 31, no. 2, 2017.

[52] Z. Wang, K.-W. Zhang, G. Wei, B. Li, Q. Li, and W.-J. Yao, "Field measurement analysis of the influence of double shield 
tunnel construction on reinforced bridge," Tunnelling and Underground Space Technology, vol. 81, pp. 252-264, 2018.

[53] J. Bai, S. Li, Y. Jiang, R. Liu, Z. Li, and W. Li, "An extension theoretical model for grouting effect evaluation in sand stratum of metro construction," KSCE Journal of Civil Engineering, vol. 23, no. 5, pp. 2349-2358, 2019.

[54] J.-S. Yang, C. Zhang, J.-Y. Fu, S.-Y. Wang, X.-F. Ou, and Y.-P. Xie, "Pre-grouting reinforcement of underwater karst area for shield tunneling passing through Xiangjiang river in Changsha, China," Tunnelling and Underground Space Technology, vol. 100, Article ID 103380, 11 pages, 2020.

[55] P.-L. Li, Y.-Q. Lu, J.-X. Lai, H.-Q. Liu, and K. Wang, "A comparative study of protective schemes for shield tunneling adjacent to pile groups," Advances in Civil Engineering, vol. 2020, Article ID 6964314, 16 pages, 2020. 